Article

\title{
Application of High-Throughput Assays to Examine Phospho-Modulation of the Late Steps of Regulated Exocytosis
}

\author{
Prabhodh S. Abbineni ${ }^{1,+}$ and Jens R. Coorssen ${ }^{2, *}$ \\ 1 Department of Molecular Physiology, and the WSU Molecular Medicine Research Group, \\ School of Medicine, Western Sydney University, Campbelltown, NSW 2560, Australia; pabbinen@umich.edu \\ 2 Faculty of Applied Health Sciences and Faculty of Mathematics and Science, Brock University, \\ St. Catharines, ON L2S 3A1, Canada \\ * Correspondence: jcoorssen@brocku.ca; Tel.: +1-90-5688-5550 \\ + Present address: Department of Pharmacology, University of Michigan Medical School, \\ Ann Arbor, MI 48109, USA.
}

Academic Editor: Massimo Negrini

Received: 20 September 2017; Accepted: 6 November 2017; Published: 13 November 2017

\begin{abstract}
Regulated exocytosis enables a range of physiological functions including neurotransmission, and the late steps (i.e., docking, priming and $\mathrm{Ca}^{2+}$-triggered membrane fusion) are modulated by a highly conserved set of proteins and lipids. Many of the molecular components and biochemical interactions required have been identified; the precise mechanistic steps they modulate and the biochemical interactions that need to occur across steps are still the subject of intense investigation. Particularly, although the involvement of phosphorylation in modulating exocytosis has been intensively investigated over the past three decades, it is unclear which phosphorylation events are a conserved part of the fundamental fusion mechanism and/or serve as part of the physiological fusion machine (e.g., to modulate $\mathrm{Ca}^{2+}$ sensitivity). Here, the homotypic fusion of cortical vesicles was monitored by utilizing new high-throughput, cost-effective assays to assess the influence of 17 small molecule phospho-modulators on docking/priming, $\mathrm{Ca}^{2+}$ sensitivity and membrane fusion. Specific phosphatases and casein kinase 2 are implicated in modulating the $\mathrm{Ca}^{2+}$ sensitivity of fusion, whereas sphingosine kinase is implicated in modulating the ability of vesicles to fuse. These results indicate the presence of multiple kinases and phosphatases on the vesicles and critical phosphorylation sites on vesicle membrane proteins and lipids that directly influence late steps of regulated exocytosis.
\end{abstract}

Keywords: phosphorylation; docking; priming; membrane fusion; calcium sensitivity; lipids; secretory vesicles

\section{Introduction}

Eukaryotic cells release select compounds via regulated exocytosis in order to enable a range of physiological functions (e.g., neurotransmission, immunological reactions, fertilisation, wound healing, autophagy, and so forth). This regulated exocytotic pathway is often categorised into distinct functional stages including: (i) targeted trafficking of secretory vesicles to the plasma membrane; (ii) tethering at the plasma membrane; (iii) full docking; (iv) priming (which may also include pre-docking molecular changes); (v) triggering; (vi) membrane fusion; (vii) fusion pore regulation and/or expansion; and (viii) content release. Molecular components that regulate exocytosis can be broadly categorised as either modulating the efficiency of release (i.e., the physiological fusion machine (PFM) influencing parameters such as $\mathrm{Ca}^{2+}$ sensitivity and the rate of fusion) or as components of the fundamental fusion mechanism (FFM), which directly enables the process of membrane merger leading 
to the opening of the fusion pore and the release of intracellular compounds [1-5]. Several proteins and lipids, including soluble $\mathrm{N}$-ethylmaleimide-sensitive factor attachment proteins (SNAREs), cholesterol, poly-phosphatidylinositols and anionic lipids, are known to be involved in enabling and regulating different stages of the exocytotic pathway and have been confirmed as critical elements of the PFM, with a few now also confirmed as components of the FFM in native systems [1,6-11].

The activity of proteins and lipids involved in exocytosis can be modulated by kinases and phosphatases, which are capable of regulating inter-protein, inter-lipid and protein-lipid interactions or of triggering conformational changes necessary for a specific stage of the exocytotic pathway. For example, numerous studies have found that phorbol 12-myristate 13-acetate (PMA), which activates protein kinase $\mathrm{C}$ (PKC), also potentiates exocytotic release in a range of cell types [12-14]; phosphorylation of synaptosomal-associated protein 25 (SNAP-25) by PKC has been suggested to account for this by increasing the size of the readily releasable pool of vesicles in chromaffin cells [15]. However, overexpression of a SNAP-25 mutant that cannot undergo phosphorylation does not inhibit the enhancing effect of PMA in hippocampal neurons. Interpretation has been further confounded in this case by the finding that PMA also interacts with Munc13 and guanosine triphosphate (GTP)-binding proteins [16,17]. Furthermore, activation of several kinases and phosphatases has been reported to have seemingly opposing functional effects; tyrosine kinase activation has been shown to potentiate release in $\beta$ cells [18], but to act as a negative regulator, inhibiting transmitter release from neuronal cells [19]. Likewise, inhibiting calcineurin $\left(\mathrm{a} \mathrm{Ca}^{2+} /\right.$ calmodulin-dependent protein phosphatase) has been found to potentiate release from $\beta$ cells and rat cerebral cortex synaptosomes [20,21], but to inhibit the release of pepsinogen from permeabilised chief cells and to reduce secretion from the rapidly releasable pool of vesicles in hippocampal neurons [22,23].

Given these contrasting results, it has clearly been difficult to definitively correlate phosphorylation-related events with specific stages of the regulated exocytotic pathway. To some degree, this has likely been complicated by alternate and/or off-target effects of 'selective' chemical inhibitors and activators, as well as the model systems and assessment techniques (i.e., intact, permeabilised or patch clamped cells). As such, it remains to be defined which phosphorylation events enable or modulate particular stages of the exocytotic pathway and thus to discriminate between conserved features of the fundamental exocytotic machinery versus those that may have been selectively optimised over evolution to 'tune' specific physiological responses.

As cortical vesicles (CV) isolated from sea urchin oocytes are locked in a fully primed, release-ready state, they are an ideal, well-established model with which to assess the role(s) of highly conserved proteins and lipids in the $\mathrm{Ca}^{2+}$-triggered stages of exocytosis [2,3,5,7-10,24-28]. The sea urchin genome encodes for all of the kinase classes present in vertebrates $[29,30]$, and CV membrane-associated proteins and lipids are known to be sufficient for docking, $\mathrm{Ca}^{2+}$ sensing and membrane fusion via a mechanistic pathway that is by all accounts identical to vesicle-plasma membrane fusion $[7,24,26,31,32]$. Therefore, if a (de)phosphorylation event is required to enable or modulate the $\mathrm{Ca}^{2+}$ triggered steps of regulated exocytosis, the kinase(s) and phosphatase(s) responsible likely target components of the secretory vesicle membrane and are perhaps components themselves. Kinases present in the cytosol or plasma membrane could also be involved in modulating the PFM, but their influence would not be detected in this study (although the assay could clearly be modified by also adding isolated cytosol to address this). It would however seem reasonable to expect that any components critical to the late mechanistic steps of exocytosis would be preferentially localized to the $\mathrm{CV}$ and/or to vesicle-plasma membrane contact sites. Here, we have used CV and minimised docking and membrane fusion assays to screen a selection of well-characterised small molecule (including peptide) modulators of phosphorylation. Two sub-maximal doses of $\left[\mathrm{Ca}^{2+}\right]_{\text {free }}$ were used to trigger a fraction of $\mathrm{CV}$ to fuse, and this minimised assay enabled us to rapidly screen for effects on $\mathrm{Ca}^{2+}$ sensitivity. This approach is fundamentally similar to one previously utilised by Vogel et al. [33] to identify membrane active drugs; however, that study focussed on a generic testing of drugs by utilising cell surface complexes (sheets of plasma membrane with endogenously docked CV), which 
do not enable discrimination of drug effects on docking/priming and membrane fusion, which was made possible here by monitoring homotypic $\mathrm{CV}$ fusion using minimised $\mathrm{Ca}^{2+}$ activity assays of docking and fusion. The resulting high-throughput, microplate reader-based assays enabled massively parallel screening not possible with the full activity assay formats previously employed. The results implicate specific kinases and phosphatases in enabling and modulating the fundamental mechanisms underlying the late $\mathrm{Ca}^{2+}$ triggered steps of regulated exocytosis.

\section{Materials and Methods}

\subsection{Materials}

Heliocidaris tuberculate (red sea urchins) were collected under government licence from Shellharbour and La Perouse (NSW, Australia) and stored in aquaria at $10{ }^{\circ} \mathrm{C}$ in the aquatic facility of Western Sydney University. Phorbol 12-myristate 13-acetate (PMA) and staurosporine were purchased from Sigma Aldrich (St. Louis, MO, USA); okadaic acid was from Calbiochem (San Diego, CA, USA); and all other small molecule phosphorylation inhibitors were from Tocris (Ellisville, MO, USA). Double glass-distilled water $\left(\mathrm{ddH}_{2} \mathrm{O}\right)$ was used throughout. All fusion assays were performed using the POLARstar Omega plate reader (BMG Labtech, Offenburg, Germany).

\subsection{Isolation of Cortical Vesicles and Drug Treatments}

Cortical vesicles were isolated from urchin oocytes as previously described, with some modifications $[5,24,27]$. Cell surface complexes (CSC), large plasma membrane fragments with endogenous docked vesicles, were obtained by homogenising oocytes on ice and isolated by centrifugation at $700 \times g$ for $5 \mathrm{~min}$. Cell surface complexes were then washed free of cytosolic components using ice cold intracellular medium (IM; $210 \mathrm{mM}$ glutamate (free acid), $0.5 \mathrm{M}$ glycine, $10 \mathrm{mM} \mathrm{NaCl}, 10 \mathrm{mM}$ piperazine- $N, N^{\prime}$-bis(2-ethanesulfonic acid (PIPES), $1.1 \mathrm{mM} \mathrm{MgCl} 2$ and 5 mM EGTA, pH 6.7) and then incubated in PKME buffer (50 mM PIPES (free acid), $425 \mathrm{mM} \mathrm{KCl,}$ $10 \mathrm{mM} \mathrm{MgCl} 2,5 \mathrm{mM}$ ethylene glycol-bis( $\beta$-aminoethyl ether)- $N, N, N^{\prime}, N^{\prime}$-tetraacetic acid (EGTA), $\mathrm{pH} 8.0(\mathrm{KOH})$ ) for $30 \mathrm{~min}$ to disassociate $\mathrm{CV}$ from the plasma membrane. Cortical vesicles were than isolated from plasma membrane fragments by centrifugation at $700 \times g$ for $5 \mathrm{~min}$, followed by centrifugation at $2000 \times g$ for $20 \mathrm{~min}$ to obtain a high purity pellet of CV. All functional assays and incubations with small-molecule activators and inhibitors were carried out in baseline intracellular medium (BIM; $210 \mathrm{mM}$ glutamate (free acid), $0.5 \mathrm{M}$ glycine, $10 \mathrm{mM} \mathrm{NaCl}, 10 \mathrm{mM}$ PIPES (free acid), $0.05 \mathrm{mM} \mathrm{CaCl}_{2}, 1 \mathrm{mM} \mathrm{MgCl} 2,1 \mathrm{mM}$ EGTA) supplemented with $2.5 \mathrm{mM}$ ATP, protease inhibitors and $2 \mathrm{mM}$ dithiothreitol (DTT) $[8,9,26,27]$. Cortical vesicles treatments and endpoint and settle fusion assays were performed as previously described $[7,9,10,27,34]$. Briefly, CV were treated with the indicated concentrations of drugs for $20 \mathrm{~min}$ at $25^{\circ} \mathrm{C}$ at an optical density $\left(\mathrm{OD}_{405}\right)$ of 1.0 and immediately diluted with ice-cold BIM. $\alpha$-naphthyl phosphate $(\alpha-\mathrm{NP})$ was delivered from a $500 \mathrm{mM}$ stock prepared in $\mathrm{ddH}_{2} \mathrm{O}$, and all other small molecules were delivered from concentrated stocks in dimethyl sulfoxide (DMSO); the final solvent concentration was $\leq 1 \%$, and although it was confirmed to have no effect on the fusion assays [35], this vehicle was nonetheless added to all controls. Drug concentrations utilised in this study were identified in the literature using PubMed, and in many cases, the compounds used here have been used to assess the exocytotic mechanism in several cell types; see Table 1 for list of drugs, their molecular targets, concentration used and references. Cortical Vesicles density was adjusted to $\mathrm{OD}_{405}$ of $0.3-0.4$ for functional assays. In the endpoint assay, $\mathrm{CV}$ were dispensed into multi-well plates and centrifuged at $1000 \times g$ for $10 \mathrm{~min}$ to bring them into contact, and $\mathrm{Ca}^{2+}$ was subsequently added to trigger fusion. In the 'settle' assay (which allows vesicles to come into contact utilising endogenous docking machinery), $\mathrm{CV}$ were left for $1 \mathrm{~h}$ at room temperature (RT) to make inter-membrane attachments before the addition of $\mathrm{Ca}^{2+}$. 


\subsection{High-Throughput Methodology}

Sub-maximal doses of $\left[\mathrm{Ca}^{2+}\right]_{\text {free }}$ trigger a fraction of $\mathrm{CV}$ to fuse, and CV fusion vs. $\left[\mathrm{Ca}^{2+}\right]_{\text {free }}$ is best described by a sigmoidal $\mathrm{Ca}^{2+}$ activity curve [24,36]. Changes in $\mathrm{CV}$ fusion triggered by sub-maximal doses of $\left[\mathrm{Ca}^{2+}\right]_{\text {free }}$ are indicative of changes to the $\mathrm{Ca}^{2+}$ sensitivity of the mechanism(s), while alterations in the response to saturating doses of $\left[\mathrm{Ca}^{2+}\right]_{\text {free }}(\sim 1 \mathrm{mM})$ indicate changes to the capacity for vesicles to fuse (i.e., the ability to fuse). In this study, minimised versions of standard endpoint and settle $\mathrm{Ca}^{2+}$ activity assays were used to enable high-throughput screening of all the test compounds. Two sub-maximal doses of $\left[\mathrm{Ca}^{2+}\right]_{\text {free }}\left(38.8 \pm 1.7 \mu \mathrm{M}\right.$ and $\left.69.8 \pm 4.8 \mu \mathrm{M}\left[\mathrm{Ca}^{2+}\right]_{\text {free }}\right)$ were used to trigger $\mathrm{CV}$ fusion and were designated as ' $\mathrm{low}^{\prime}$ and 'medium' $\mathrm{Ca}^{2+}$, respectively, in the endpoint assay; $60.7 \pm 1.5 \mu \mathrm{M}\left[\mathrm{Ca}^{2+}\right]_{\text {free }}$ and $91.2 \pm 4.3 \mu \mathrm{M}\left[\mathrm{Ca}^{2+}\right]_{\text {free }}$ were designated as low and medium $\mathrm{Ca}^{2+}$, respectively, in the settle assay. In both assay formats, responses to $1 \mu \mathrm{M}$ and $\geq 1 \mathrm{mM}$ $\left[\mathrm{Ca}^{2+}\right]_{\text {free }}$ were defined as $0 \%$ and $100 \%$ fusion, respectively; as is standard for such $\mathrm{Ca}^{2+}$ activity assays, $\geq 1 \mathrm{mM}\left[\mathrm{Ca}^{2+}\right]_{\text {free }}$ was thus defined as 'high' $\mathrm{Ca}^{2+}$. Thus, here, monitoring changes in the range of $\left[\mathrm{Ca}^{2+}\right]_{\text {free }}$ corresponding to the rising phase of the standard sigmoidal $\mathrm{Ca}^{2+}$ activity curves enabled us to carry out broadly parallel assays with high throughput and thus scan and identify small molecules that altered the $\mathrm{Ca}^{2+}$ sensitivity of fusion. Sigmoidal curves were plotted using responses to low and medium doses of $\left[\mathrm{Ca}^{2+}\right]_{\text {free }}$ to estimate the transition phase of the sigmoid curve in order to obtain an initial estimate of the half maximum effective concentration $\left(\mathrm{EC}_{50}\right)$. Treatments that were found to significantly alter CV fusion responses to both the low and medium doses of $\left[\mathrm{Ca}^{2+}\right]_{\text {free }}$ in the endpoint assay were further assessed using a range of $\left[\mathrm{Ca}^{2+}\right]_{\text {free }}$ in order to better define the $\mathrm{EC}_{50}$ from full $\mathrm{Ca}^{2+}$ activity curves. In all assays, $\left[\mathrm{Ca}^{2+}\right]_{\text {free }}$ was measured in parallel mock solutions using a $\mathrm{Ca}^{2+}$-sensitive electrode (EDT directION, Dover, UK), calibrated using CALBUF $\mathrm{Ca}^{2+}$ standards (World Precision Instruments, Sarasota, FL, USA) [24,25]. All compounds were tested using material from a minimum of three different biological preparations, and each experiment was carried out using three technical replicates. Drug treatments were varied across different experiments. All results are presented as the mean \pm SEM. A Shapiro-Wilk test was performed to confirm that the data are normally distributed. The two-tailed Student's $t$-test was used to assess statistical significance, and $p<0.05$ was considered significant.

\section{Results}

Seventeen small molecule modulators of phosphorylation (Table 1) were screened for their effect on CV fusion in minimised endpoint and settle assay formats with the aim of identifying candidate kinases and phosphatases that enable or modulate the late $\mathrm{Ca}^{2+}$-triggered steps of regulated exocytosis. Changes to $\mathrm{CV}$ fusion in response to low and medium doses of $\left[\mathrm{Ca}^{2+}\right]_{\text {free }}$ in the endpoint assay are indicative of changes in $\mathrm{Ca}^{2+}$ sensitivity, whereas changes in the settle assay (i.e., relative to the endpoint assay) are indicative of alterations to attachment/priming factors $[8,9,27]$. Inhibition of CV fusion in response to saturating $\left[\mathrm{Ca}^{2+}\right]_{\text {free }}(\mathrm{mM})$ in the endpoint assays is indicative of alterations to the membrane fusion machinery, as this assay is thought to bypass the need for those endogenous components required for priming and attachment. Small molecules found to alter CV fusion in response to low and medium doses of $\left[\mathrm{Ca}^{2+}\right]_{\text {free }}$ in the minimised endpoint assay were tested again using a more detailed standard $\mathrm{Ca}^{2+}$ activity assay $\left(\mathrm{CV}\right.$ fusion versus $\left.\left[\mathrm{Ca}^{2+}\right]_{\text {free }}\right)$ to best measure $\mathrm{EC}_{50}$.

Table 1. List of compounds utilised in this study, their molecular targets and references from which the effective dose was identified.

\begin{tabular}{cccc}
\hline Compound & Molecular Target & Dose Used & Refs \\
\hline Phorbol 12-myristate 13-acetate (PMA) & PKC activator & $100 \mathrm{nM}$ & {$[12,14,37-40]$} \\
\hline Gö 6983 & PKC inhibitor & $10 \mu \mathrm{M}$ & {$[41-46]$} \\
\hline $\begin{array}{c}\text { PKC inhibitory peptide (19-36; } \\
\text { RFARKGALRQKNVHEVKN) }\end{array}$ & PKC inhibitor & $10 \mu \mathrm{M}$ & {$[13,47,48]$} \\
\hline Staurosporine & Broad spectrum kinase inhibitor & $4 \mu \mathrm{M}$ & {$[49-58]$} \\
\hline
\end{tabular}


Table 1. Cont.

\begin{tabular}{|c|c|c|c|}
\hline Compound & Molecular Target & Dose Used & Refs \\
\hline$\alpha$-naphthyl phosphate $(\alpha-\mathrm{NP})$ & $\begin{array}{l}\text { Broad spectrum } \\
\text { phosphatase inhibitor }\end{array}$ & $5 \mathrm{mM}$ & [14] \\
\hline Okadaic acid & $\begin{array}{l}\text { Dual protein phosphatase } \\
1 / 2 \mathrm{~A} \text { inhibitor }\end{array}$ & $1 \mu \mathrm{M}$ & {$[12,20,28,59-62]$} \\
\hline $\begin{array}{l}\text { Calcineurin (CaN) inhibitory peptide } \\
\text { (457-482; } \\
\text { ITSFEEAKGLDRINERMPPRRDAMP) }\end{array}$ & CaN inhibitor & $100 \mu \mathrm{M}$ & {$[20,63]$} \\
\hline $\begin{array}{l}\text { PKA inhibitory peptide (6-22; } \\
\text { TYADFIASGRTGRRNAI) }\end{array}$ & Protein kinase A inhibitor & $1 \mu \mathrm{M}$ & [64-66] \\
\hline 4,5,6,7-tetrabromobenzotriazole (TBB) & Casein kinase 2 (Ck2) inhibitor & $25 \mu \mathrm{M}$ & {$[67,68]$} \\
\hline GSK 429286 & Rho kinase (ROCK) inhibitor & $2 \mu \mathrm{M}$ & [69-72] \\
\hline Bosutinib & Dual abl/src kinase inhibitor & $10 \mu \mathrm{M}$ & [73-76] \\
\hline A419259 & Src kinase inhibitor & $500 \mathrm{nM}$ & [77-81] \\
\hline $\begin{array}{c}\text { Autocamtide-2-related inhibitory } \\
\text { peptide (AIP) (KKALRRQEAVDAL) }\end{array}$ & $\begin{array}{l}\text { Calmodulin-dependent protein } \\
\text { kinase II (CaMK II) inhibitor }\end{array}$ & $10 \mu \mathrm{M}$ & {$[82,83]$} \\
\hline STO609 & $\begin{array}{l}\mathrm{Ca} 2^{+} / \text {calmodulin-dependent } \\
\text { protein kinase kinase } \\
\text { (CaMK kinase) inhibitor }\end{array}$ & $25 \mu \mathrm{M}$ & [84-87] \\
\hline R59022 & Diacylglycerol kinase inhibitor & $12.5 \mu \mathrm{M}$ & {$[88,89]$} \\
\hline NVP231 & Ceramide kinase inhibitor & $100 \mathrm{nM}$ & [90-93] \\
\hline Dimethylsphingosine (DMS) & Sphingosine kinase inhibitor & $100 \mu \mathrm{M}$ & [94] \\
\hline
\end{tabular}

PKC: Protein kinase C; PKA: Protein kinase A.

\subsection{Effects of Protein Kinase Inhibitors}

We first tested the effect of treating CV with the broad spectrum kinase inhibitor, staurosporine [95]. In the endpoint assay, $4 \mu \mathrm{M}$ staurosporine caused a reduction in $\mathrm{CV}$ fusion in response to low doses of $\left[\mathrm{Ca}^{2+}\right]_{\text {free }}$, suppressed the total extent of $\mathrm{CV}$ fusion by $8.2 \% \pm 1.6 \%$, but had no effect in the settle assay (Figure 1(Ai,Bi)). Although staurosporine is often utilised as a 'broad-spectrum' kinase inhibitor at low micromolar doses, substantially higher concentrations than used here are known to be required to inhibit certain kinases (e.g., $>100 \mu \mathrm{M}$ is required to inhibit casein kinase-1 [96]); however, possible off-target effects involving inhibition of other ATP-binding proteins have been reported, making the effects of higher doses of the drug difficult to interpret [97]. As such, a range of well-characterised, selective small-molecule modulators of phosphorylation were also utilised to test the role(s) of kinase activities in the late steps of regulated exocytosis. Nine of the small molecules tested inhibit protein kinase activities, and of these, only treatment with 4,5,6,7-tetrabromobenzotriazole (TBB), an inhibitor of casein kinase-2, was found to alter CV fusion in response to both low and medium doses of $\left[\mathrm{Ca}^{2+}\right]_{\text {free }}$. Treatment with $25 \mu \mathrm{M}$ TBB promoted the extent of $\mathrm{CV}$ fusion in response to low and medium doses of $\left[\mathrm{Ca}^{2+}\right]_{\text {free }}$ from control values of $25.6 \% \pm 3.9 \%$ and $68.9 \% \pm 5.7 \%$ to $38.3 \% \pm 4 \%$ and $88.5 \% \pm 2.5 \%$, respectively (Figure 1 (Aii)). Standard endpoint $\mathrm{Ca}^{2+}$ activity assays confirmed a potentiation of $\mathrm{Ca}^{2+}$ sensitivity, with $\mathrm{EC}_{50}$ being left-shifted from $52.0 \pm 2.5 \mu \mathrm{M}$ to $33.6 \pm 5.7 \mu \mathrm{M}$ $\left[\mathrm{Ca}^{2+}\right]_{\text {free }}$ (Figures 2A and 3A; $\left.p<0.05\right) .4,5,6,7-$ Tetrabromobenzotriazole also potentiated the extent of $\mathrm{CV}$ fusion in the settle assay in response to a medium dose of $\left[\mathrm{Ca}^{2+}\right]_{\text {free }}$ without significantly altering the $\mathrm{EC}_{50}$ (Figure $3 \mathrm{~B}$ ). The data thus indicate a native role for casein kinase 2 in negatively modulating $\mathrm{Ca}^{2+}$ sensitivity.

Treatment of CV with small molecule inhibitors of PKC, PKA and calmodulin-dependent protein kinase II (CaMK II) caused $61.3 \% \pm 10.4 \%$ inhibition of fusion in response to low doses of $\left[\mathrm{Ca}^{2+}\right]_{\text {free }}$ without significantly affecting fusion in response to medium doses of $\left[\mathrm{Ca}^{2+}\right]_{\text {free }}$ (Figure 1(Ai-Aiii)), but had no effect in settle assays (Figure 1(Bi-Biii)). Inhibition of CV fusion in response to low doses of $\left[\mathrm{Ca}^{2+}\right]_{\text {free }}$ is indicative of a reduction in $\mathrm{Ca}^{2+}$ sensitivity; however, as the inhibition was overcome by medium doses of $\left[\mathrm{Ca}^{2+}\right]_{\text {free, }}$, it is likely reflective of a significant albeit selective 'tuning' of $\mathrm{Ca}^{2+}$ 
sensitivity within a particular concentration range. Thus, the overall $\mathrm{EC}_{50}$ was not found to be significantly different relative to controls (Figure 2A,B). Gö 6983, a broad-spectrum PKC inhibitor, supressed the maximal extent of CV fusion by only $4.5 \% \pm 1.1 \%$ and did not significantly alter $\mathrm{Ca}^{2+}$ sensitivity (Figure 1(Ai)). The PKC activator PMA $(100 \mathrm{nM})$ did not alter $\mathrm{Ca}^{2+}$ sensitivity (i.e., did not alter $\mathrm{CV}$ fusion in response to low and medium doses of $\left[\mathrm{Ca}^{2+}\right]_{\text {free }}$ ), but suppressed total fusion extent by $5.0 \% \pm 1.0 \%$ (Figure $1(\mathrm{Ai})$ ).
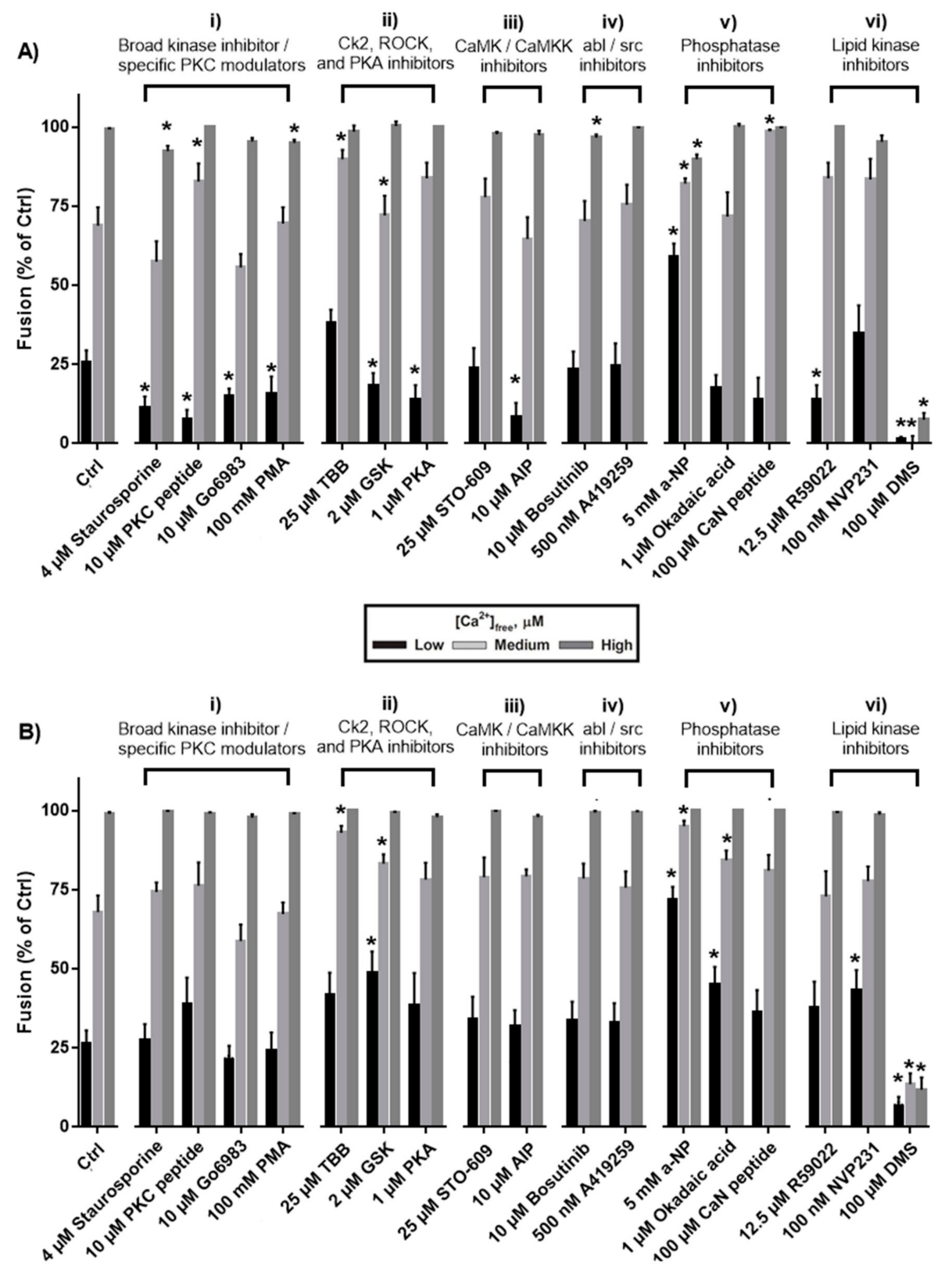

Figure 1. Effects on cortical vesicle-cortical vesicle (CV-CV) fusion in the minimised endpoint (A) and settle (B) assays broadly inhibiting (i) kinase activities (i.e., with staurosporine), as well as more selectively targeting PKC activity with activators and inhibitors $(n=3-5)$; (ii) inhibiting Ck2, ROCK and PKA ( $n=3-5)$; (iii) inhibiting CamK and CamKK ( $n=3-4)$; (iv) inhibiting abl/src kinases $(n=4-5)$; (v) broadly inhibiting phosphatase activities (i.e., with $\alpha$-naphthyl phosphate) and more selectively inhibiting protein phosphatase 1, protein phosphatase 2A and $\mathrm{CaN}(n=3-5)$; and (vi) inhibiting diacylglycerol (DAG) kinase, ceramide kinase and sphingosine kinase $(n=3-4)$ * Statistical significance from control $(p<0.05)$. CaMKK: calmodulin-dependent protein kinase kinase. 


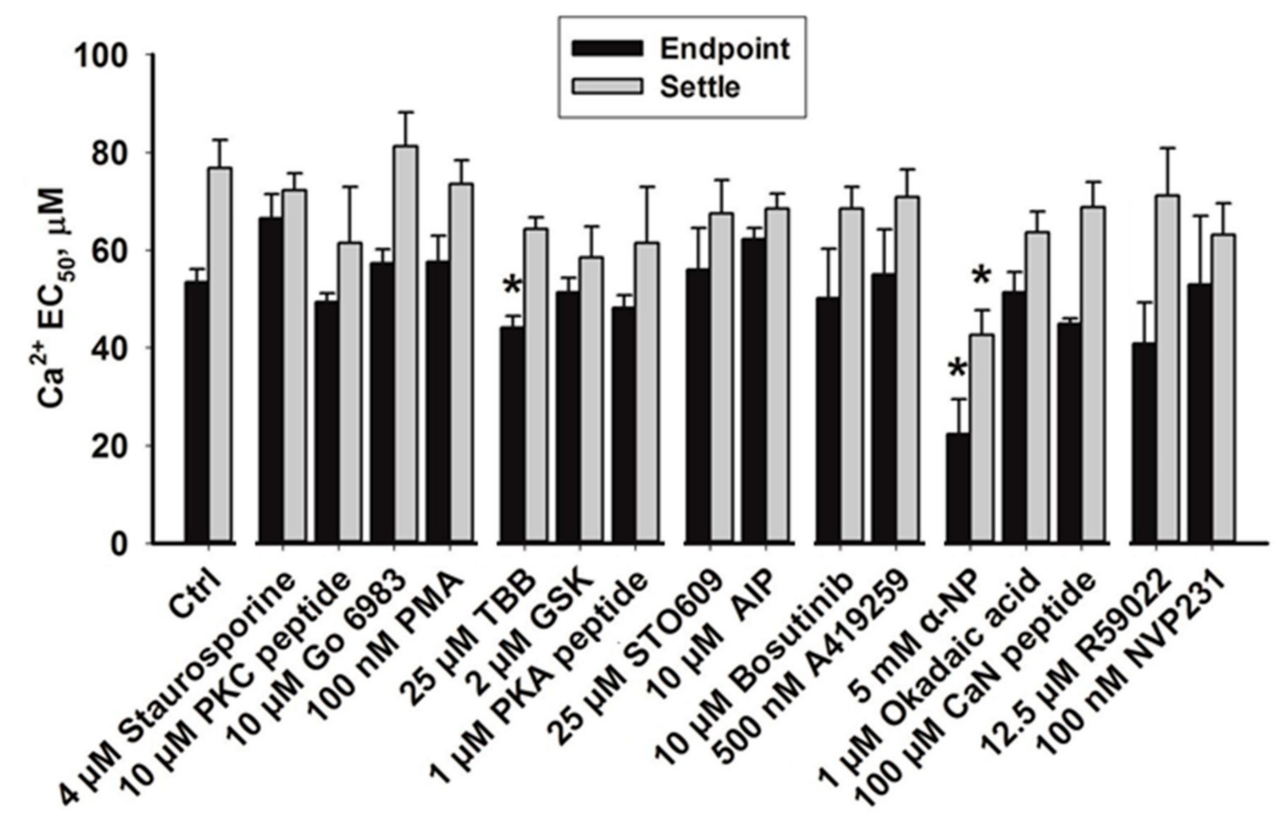

Figure 2. Half maximum effective concentration $\left(\mathrm{EC}_{50}\right)$. estimated using data from minimised endpoint and settle assays. AIP: Autocamtide-2-related inhibitory peptide.

The Rho kinase (ROCK) inhibitor, GSK 429286, had no effect on the total extent of CV fusion (Figure 1(Aii)), but selectively potentiated fusion in response to low and medium $\left[\mathrm{Ca}^{2+}\right]_{\text {free }}$ in the settle assay only (Figure 1(Bii)); the $\mathrm{EC}_{50}$ also appeared slightly left-shifted, but the effect was not significant (Figure 2B). The effects are thus indicative of an upstream role for ROCK in modulating CV docking/priming. Inhibition of abl/src kinases with bosutinib and A419259 did not significantly alter $\mathrm{CV}$ fusion in response to low and medium $\left[\mathrm{Ca}^{2+}\right]_{\text {free }}$ in the endpoint and settle assays (Figure 1(Aiv,Biv)), though bosutinib caused minor inhibition $(3.3 \% \pm 1.0 \%)$ of the final extent of fusion.

\subsection{Effects of Phosphatase Inhibitors}

Following treatment with $5 \mathrm{mM} \alpha$-naphthyl phosphate ( $\alpha$-NP), a broad-spectrum phosphatase inhibitor, CV fusion was potentiated by $60.0 \% \pm 4.7 \%$ and $22.4 \% \pm 8.8 \%$, respectively, in response to low and medium doses of $\left[\mathrm{Ca}^{2+}\right]_{\text {free }}$ in both the endpoint and settle assays (Figure $1(\mathrm{Av}, \mathrm{Bv})$ ). Standard $\mathrm{Ca}^{2+}$ activity assays confirmed a potentiation of $\mathrm{Ca}^{2+}$ sensitivity, with the control $\mathrm{EC}_{50}(52.0 \pm 2.5 \mu \mathrm{M}$ $\left.\left[\mathrm{Ca}^{2+}\right]_{\text {free }}\right)$ left-shifted to $33.6 \pm 5.5 \mu \mathrm{M}\left[\mathrm{Ca}^{2+}\right]_{\text {free }}$ in the endpoint assay and from $82.1 \pm 5.7 \mu \mathrm{M}$ to $56.8 \pm 6.9 \mu \mathrm{M}\left[\mathrm{Ca}^{2+}\right]_{\text {free }}$ in the settle assay (Figure $3 \mathrm{~A}, \mathrm{~B} ; p<0.05$ ). The change in $\mathrm{EC}_{50}$ is thus comparable in both assay formats indicating that the potentiation of $\mathrm{Ca}^{2+}$ sensitivity by $\alpha-\mathrm{NP}$ was less likely due to enhanced docking or priming since the endpoint assay is thought to bypass endogenous components essential to these early steps. Treatment with $5 \mathrm{mM} \alpha$-NP also suppressed the extent of CV fusion in the endpoint assay by $10.1 \% \pm 3.4 \%$ (Figure $1(\mathrm{Av})$ ). To narrow the list of possible phosphatases that could be causing the functional changes, okadaic acid, an inhibitor of protein phosphatases 1 and 2A, and calcineurin inhibitory peptide (CaN peptide), an inhibitor of calcineurin (CaN; protein phosphatase 3 ), were utilised. Treatment with $1 \mu \mathrm{M}$ okadaic acid increased $\mathrm{CV}$ fusion by $41.2 \% \pm 8.6 \%(p<0.05)$ only in the settle assay, in response to low and medium $\left[\mathrm{Ca}^{2+}\right]_{\text {free }}($ Figure $1(\mathrm{Bv}))$; there was no effect on the endpoint assay (Figure 1(Av)). In contrast, exposure to $100 \mu \mathrm{M} \mathrm{CaN}$ peptide selectively and maximally potentiated $\mathrm{CV}$ fusion in response to medium doses of $\left[\mathrm{Ca}^{2+}\right]_{\text {free }}$ in the endpoint assay (Figure 1(Av)), but had no significant effect in the settle assay (Figure 1(Bv)). Standard $\mathrm{Ca}^{2+}$ activity measurements revealed no changes in the $\mathrm{EC}_{50}$ following treatment with okadaic acid or CaN peptide (Figure 3A,B). 

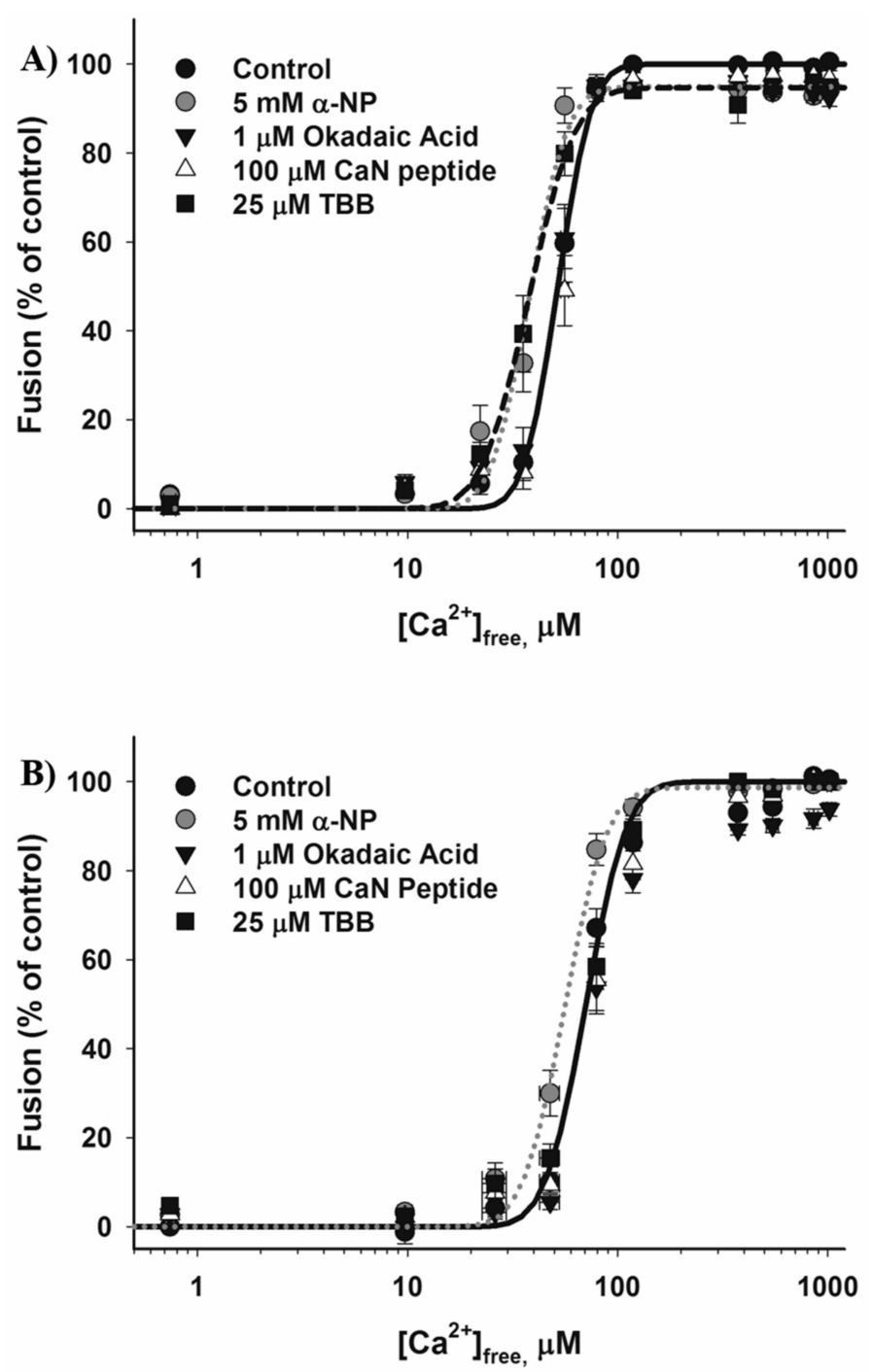

Figure 3. The effects of phosphatase inhibitors and TBB on CV-CV fusion. Full endpoint (A) and settle (B) $\mathrm{Ca}^{2+}$ activity curves $(n=3)$.

\subsection{Effects of Inhibiting Lipid Kinases}

Treatment with $12.5 \mu \mathrm{M}$ R59022, a diacylglycerol kinase inhibitor, inhibited CV fusion in response to low $\left[\mathrm{Ca}^{2+}\right]_{\text {free }}$ in the endpoint assay, but had no effect on $\mathrm{CV}$ fusion in response to any other dose of $\left[\mathrm{Ca}^{2+}\right]_{\text {free }}$ tested in the endpoint and settle assays (Figure 1(Avi,Bvi)) and did not significantly alter $\mathrm{EC}_{50}$ (Figure 2A,B). Treatments with NVP231 and dimethylsphingosine (DMS)—inhibitors of ceramide and sphingosine kinases, respectively-were used to assess the role(s) of sphingolipid phosphorylation. Treatment of CV with NVP231 increased fusion in response to a low dose of $\left[\mathrm{Ca}^{2+}\right]_{\text {free }}$ in the settle assay (Figure 1(Bvi)), but did not have any effect on responses to low and medium $\left[\mathrm{Ca}^{2+}\right]_{\text {free }}$ (Figure 1(Avi)), indicative of a role for ceramide kinase in modulating docking/priming. Treatment of CV with $100 \mu \mathrm{M}$ DMS had the most potent effects of any of the compounds tested in this study, inhibiting the extent of CV fusion by $92.4 \% \pm 2.1 \%$ and $88.2 \% \pm 3.8 \%(p<0.001)$ in the endpoint and settle assays, respectively (Figure 1(Avi,Bvi)).

\section{Discussion}

New assay formats enabling high-throughput, parallel screening were used to examine the effect of phospho-modulators on the late stages of regulated exocytosis. Whereas cell surface complexes 
were previously used to more broadly identify membrane active drugs [33], here we utilised CV, enabling us to target the late steps of the exocytotic mechanism, notably docking/priming, calcium sensitivity and triggered fusion, without the high molecular background of the plasma membrane, which is present in cell surface complexes. We assessed twelve small molecules known to modulate the activity of eleven classes of protein kinases and phosphatases, three small molecules targeting three classes of lipid kinases and two small molecules that act as broad-spectrum kinase and phosphatase inhibitors (Table 1). Of these seventeen compounds, four were found to potentiate and one to markedly inhibit fusion. None of the compounds tested affected CV integrity; changes in optical density only occurred in response to increasing $\left[\mathrm{Ca}^{2+}\right]_{\text {free }}$. Utilising both endpoint and settle assays enabled us to distinguish between effects on docking/priming versus membrane fusion, as an additional low-speed centrifugation step in the endpoint assay is thought to bypass the need for endogenous docking/priming machinery. The settle assay cannot distinguish between effects on priming versus docking, and treatments found to selectively alter CV fusion in the settle assay could be indicative of changes to either or both pre-fusion steps.

The sea urchin genome encodes for all of the kinase classes found in vertebrates, and as urchins diverged prior to the advent of whole genome duplications, their genome has a lower degree of redundancy (i.e., in many cases, subfamilies of kinases have only one member) [29,30]. As such, the sea urchin CV model system is ideal for identifying the evolutionarily-conserved components underlying the fundamental $\mathrm{Ca}^{2+}$-triggered steps of exocytosis [2,3,7-9,24-28,34]. Kinase activity is modulated via allosteric mechanisms by which binding of kinase activators (e.g., $\mathrm{Ca}^{2+}$, diacylglycerol, phospholipids) to regulatory domains results in the activation of catalytic sites (containing the ATP binding domain) that bind and phosphorylate the substrate(s). Inhibitors that bind regulatory domains, such as pseudopeptides, tend to show a higher degree of specificity than those that interact with the ATP binding domain (e.g., staurosporine) [95]. This study utilised small molecules that target a range of kinases and phosphatases, with bioinformatic analysis confirming a high degree of conservation between human kinase and phosphatase protein sequences and their urchin progenitors and orthologs (Table 2), particularly at regulatory domains and catalytic sites; this is consistent with previous studies using well-characterised small molecule inhibitors to target urchin enzymes $[8,9,27]$, as well as with the high conservation of other proteins involved in exocytosis [2]. For example, the serine/threonine catalytic domains found in many of the kinases examined are $81.1 \%$ identical and $92.7 \%$ similar between urchins and humans (Table 2). As such, screening small molecule modulators of phosphorylation enabled the identification of candidate kinases and phosphatases that modulate attachment/priming, $\mathrm{Ca}^{2+}$ sensitivity and membrane fusion. One caveat of such a screening study might be that in cases in which a test compound had no effect, the target kinase or phosphatase might not be present on the vesicle membrane. However, A419259 and STO-609, inhibitors of src kinase and CaMKK, respectively, were the only compounds tested that had no effect on any of the parameters assessed (Figure 1(Aiii,Aiv,Biii,Biv)). In the case of A419259, the dual abl/src kinase inhibitor bosutinib also had no effect except for an $\sim 3 \%$ inhibition of fusion at saturating $\left[\mathrm{Ca}^{2+}\right]_{\text {free }}$ and only in the endpoint assay. Therefore, our results are in agreement with studies showing that tyrosine phosphorylation may modulate upstream stages of exocytosis via known proteins [19,98], but provides no evidence to suggest their involvement in the modulation of late priming/docking reactions, $\mathrm{Ca}^{2+}$ sensitivity or any marked effect on fusion (Figure 2A,B). It may thus be that any substantial modulatory influence of tyrosine phosphorylation may occur via target components in the plasma membrane. Similarly, although we have previously established that there is substantial calmodulin on the CV membrane [2], the data here are not consistent with a role for CaMKK except perhaps at the plasma membrane [99], although that would require verification by alternate studies. 
Table 2. Conservation of kinase and phosphatase amino acid sequences from sea urchin to human.

\begin{tabular}{ccc}
\hline Enzyme Name & Percent Identity & Percent Similarity \\
Protein kinase C & 68.4 & 80 \\
PKC conserved region 1 (phorbol ester binding site) & 90 & 92 \\
Serine/threonine catalytic domain & 81.1 & 92.7 \\
Casein kinase 2 $\alpha$ subunit & 78.7 & 89.8 \\
Abl-related protein tyrosine kinase & 79.1 & 86.9 \\
Src-family protein tyrosine kinase & 69.1 & 80.6 \\
Rho kinase & 54.4 & 67.9 \\
Rho kinase associated coiled coil (containing PH domain) & 47.2 & 64.4 \\
Calmodulin-dependent protein kinase 1 & 55.4 & 69.6 \\
Calmodulin-dependent protein kinase kinase & 57.6 & 76.6 \\
Protein phosphatase 2A catalytic subunit & 33.4 & 44.3 \\
Calcineurin B homologous protein & 94.4 & 97.4 \\
Diacylglycerol kinase & 62.2 & 74.0 \\
Ceramide kinase & 52.8 & 65.8 \\
Sphingosine kinase & 44.8 & 66.5 \\
C 1 & 43.3 & 61.0 \\
C 2 & & \\
C 3 & 64.7 & 76.5 \\
C 4 & 40.0 & 72.0 \\
C 5 & 75.0 & 91.7 \\
\hline
\end{tabular}

\subsection{Protein Kinase C, Protein Kinase A, Calmodulin-dependent Protein Kinase II}

Treatment of CV with inhibitors of PKC, PKA and CaMK II inhibited fusion in response to low $\left[\mathrm{Ca}^{2+}\right]_{\text {free, }}$, but not that triggered by a slightly higher, but still submaximal dose of $\left[\mathrm{Ca}^{2+}\right]_{\text {free }}$ (Figure 1(Ai)). Consistent with a previous assessment of the role of CaMK I (and calmodulin) using the $\mathrm{CV}$ model system, the results here also showed that the $\mathrm{EC}_{50}$ was not altered (Figure 2A,B) [2]. Inhibition in response to low $\left[\mathrm{Ca}^{2+}\right]_{\text {free }}$ was only observed in the endpoint assay, but not the settle assay, indicative of selective changes to $\mathrm{Ca}^{2+}$ sensitivity that did not result in significant changes to $\mathrm{EC}_{50}$. Studies of regulated exocytosis in mammalian cells have generally found similar effects following the modulation of protein kinase activity, such that higher $\left[\mathrm{Ca}^{2+}\right]_{\text {free }}$ 'overcome' inhibition observed at lower $\left[\mathrm{Ca}^{2+}\right]_{\text {free, }}$ or potentiation of release following the activation of kinases is significantly more potent at low doses of $\left[\mathrm{Ca}^{2+}\right]_{\text {free }}[37,100]$. As mammalian cells contain functionally distinct pools of secretory vesicles (broadly defined as those belonging to slowly and rapidly releasable pools), changes in rates of secretion can either reflect changes in the sizes of particular vesicle pools or changes to the $\mathrm{Ca}^{2+}$ sensitivity of triggering and fusion. In the case of PKC, treatment of neuronal [100], neuroendocrine [13,37], haematopoietic [14] and $\beta$ cells [12] with PMA has been shown to potentiate exocytotic release. However, PMA has also been found to bind Munc13, Rac GTPase activating proteins and guanine nucleotide-exchange factors, complicating interpretation of the release-enhancing effects. Nonetheless, overexpression of phosphomimetic mutants (i.e., at the PKC phosphorylation site) of SNAP25 and Munc18 has been found to mimic the effects of PMA [15]; treatment with specific inhibitors of PKC, such as the inhibitory peptide, have proven more selective than PMA [13,100,101]. Electrophysiological and optical studies of chromaffin cells have found an increase in the rapidly releasable pool of vesicles following activation of PKC [102], whereas studies of neuronal cells have found increases in the probability of release, without changes to pool sizes, reflective of alterations in $\mathrm{Ca}^{2+}$ sensitivity $[100,101,103]$. Here, following treatment with Gö 6983 and PKC inhibitory peptide, $\mathrm{CV}$ fusion triggered by low $\left[\mathrm{Ca}^{2+}\right]_{\text {free }}$ was inhibited, but the response to medium $\left[\mathrm{Ca}^{2+}\right]_{\text {free }}$ was not altered, and there was no significant change in $\mathrm{Ca}^{2+}$ sensitivity (Figure $1(\mathrm{Ai}, \mathrm{Bi}$ ) and Figure 2A,B). Furthermore, PMA did not potentiate $\mathrm{Ca}^{2+}$ sensitivity (Figure 1(Ai) and Figure 2A,B). Furthermore, treatment of CV with $100 \mathrm{nM}$ Gö 6983 and $100 \mathrm{nM}$ PMA did not alter the rate of fusion triggered by $\sim 500 \mu \mathrm{M}\left[\mathrm{Ca}^{2+}\right]_{\text {free }}[35]$. In neuroendocrine cells, intracellular treatment with PMA (i.e., using 
permeabilised cells or by perfusion via a patch pipette) caused rapid translocation of the enzyme to the plasma membrane, and treating permeabilised neuroendocrine cells with PKC inhibitors without prior exposure to PMA had no effect on $\mathrm{Ca}^{2+}$ sensitivity [13]. Here, $\mathrm{CV}$ were treated in the absence of cytosolic components, and only CV membrane-associated PKC activity (or Munc13 and other phorbol ester receptors) could have been modulated. Thus, it is likely that very low levels of PKC are associated with isolated CV. As CV fusion was not found to be significantly altered in the settle assay following treatment with PKC modulators, we find no evidence to suggest that PKC is involved in late priming/docking reactions; instead, the small, selective inhibition in response to low $\left[\mathrm{Ca}^{2+}\right]_{\text {free }}$ in the endpoint assay likely reflects selective, albeit limited, modulation of a $\mathrm{Ca}^{2+}$ sensor. Nonetheless, the activities of PKA, CaMK II and CaMKK have been reported to modulate stages upstream of the late $\mathrm{Ca}^{2+}$-triggered steps of exocytosis [99]. It is likely that such upstream modulation was not reflected in the settle assay as CV are fully docked and release-ready, and there are no reserve pools that require additional steps to become fusion-competent; all such maturation reactions apparently occur during early oogenesis [104]. Thus, PKC, PKA, CaMK II and CamKK, along with other recently investigated enzymes [8,27], can modulate the efficiency of the subsequent fusion response as components of the physiological fusion machinery and could have selective influences on a $\mathrm{Ca}^{2+}$ sensor $[1,2,8,9]$. Studies linking PKC activity to the modulation of fusion pore expansion [14] are consistent with this interpretation. As the assays utilised here do not assess fusion pore expansion per se, we cannot comment further on potential modulation via such a mechanism.

\subsection{Rho Kinase}

Rho kinase (ROCK activity is modulated by the Rho family of small GTPases, and ROCK is known to phosphorylate proteins involved in exocytosis (e.g., syntaxin-1 [105]). Several studies have reported an inhibition of exocytotic release following activation of ROCK. Treatment of primary pancreatic $\beta$-cells with ROCK inhibitors potentiated insulin release apparently by accelerating the depolymerisation of actin and thus likely facilitating vesicle-plasma membrane contact [106], and activation of the catalytic domain of ROCK inhibited release of human growth hormone from PC12 cells (with this effect also seen following overexpression of constitutively active mutants of Rho GTPases) [107]. Treatment of rat brain cortical synaptosomes with a ROCK inhibitor, Y27632, potentiated KCl-triggered exocytosis, whereas a myosin phosphatase inhibitor inhibited exocytosis. In this study, GSK 429286, a highly selective ROCK inhibitor, was shown to selectively potentiate CV fusion in the settle assay (Figure 1(Bii)), implicating the kinase as a negative regulatory component of priming/docking and, thus, a modulator of the late steps of exocytosis.

\subsection{Casein Kinase 2}

Casein kinase 2 (CK2) is known to phosphorylate several proteins involved in regulated exocytosis, including syntaxin 1-A [108] and synaptobrevin [109]. In vitro, phosphorylation of syntaxin $1 \mathrm{~A}$ by $\mathrm{CK} 2$ enhances its binding to the $\mathrm{C} 2 \mathrm{~B} \mathrm{Ca}^{2+}$ binding domain of synaptotagmin 1 and its interaction with Munc18 [108], and phosphorylation of complexin by CK2 enhances its binding to the SNARE complex [110]. Treatment of rat brain synaptosomes with $25 \mu \mathrm{M}$ 2-dimethylamino-4,5,6,7-tetrabromo-1 $H$-benzimidazole (DMAT) resulted in potentiation of the rate of glutamate release, and this change correlated with a reduction of syntaxin 1A phosphorylation in detergent-resistant membranes [111]. Here, the same dose of TBB (a new class of CK2 inhibitor derived from DMAT) selectively potentiated the $\mathrm{EC}_{50}$ for $\mathrm{Ca}^{2+}$ in the endpoint assay (Figure 3A), implicating CK2 in the modulation of $\mathrm{Ca}^{2+}$ sensitivity. Previous studies have implicated SNARE proteins in promoting or maintaining the $\mathrm{Ca}^{2+}$ sensitivity of fusion in a physiologically-relevant range [24-26], and phosphorylation mediated protein-protein interactions are clearly implicated in facilitating SNARE interactions that contribute to vesicle docking/priming and thus subsequent efficient release [112]. 


\subsection{Dephosphorylation}

The data here indicate that multiple phosphatases are present and active on the CV membrane and thus represent fundamental components of the late steps of triggered release. CV fusion was potentiated in the endpoint assay by $\alpha-\mathrm{NP}$ and CaN peptide, whereas okadaic acid selectively potentiated fusion in the settle assay and had no effect in the endpoint assay (Figure 1(Aii,Bii) and Figure 3A,B), in agreement with a previous study showing that okadaic acid had no effect on CV-plasma membrane fusion [28]. As okadaic acid targets protein phosphatases 1 and 2A, this suggests their involvement in the modulation of priming/docking. Furthermore, $\alpha-\mathrm{NP}$ also had a pronounced effect on $\mathrm{Ca}^{2+}$ sensitivity, significantly lowering the $\mathrm{EC}_{50}$ for fusion (Figure $3 \mathrm{~A}, \mathrm{~B}$ ), and the activity of $\mathrm{CaN}$ was also implicated in the modulation of $\mathrm{Ca}^{2+}$ sensitivity (Figure $1(\mathrm{Av}, \mathrm{Bv})$ ). As neither okadaic acid nor CaN peptide mimicked the effects of $\alpha-\mathrm{NP}$, it is likely that other phosphatases present on the $\mathrm{CV}$ membrane further influence the late $\mathrm{Ca}^{2+}$-triggered steps of regulated exocytosis. Furthermore, as the leftward shift in $\mathrm{EC}_{50}$ following treatment with $\alpha$-NP was comparable in the endpoint and settle assays (Figure 3A,B), we cannot directly discriminate between effects on $\mathrm{Ca}^{2+}$ sensitivity versus those on priming and docking. Nonetheless, previous studies have found more pronounced effects in the settle assay when priming components are targeted [8,9,27], and it thus seems likely that treatment with $\alpha$-NP does influence $\mathrm{Ca}^{2+}$ sensitivity, perhaps of the docking, priming and fusion steps; indeed, the inhibitory effects of $\alpha$-NP indicate a potentiating role on fusion pore expansion for an as yet unknown phosphatase [14]. In addition to potentiating effects, $\alpha$-NP also caused minor inhibition of the extent of fusion, further suggesting the presence of multiple phosphatases that play diverse roles to regulate the late stages of exocytosis. Overall, our data indicate that inhibiting phosphatase activity potentiates release, and this is in agreement with findings in numerous cell types, though further work is required to identify the specific interactions that modulate $\mathrm{Ca}^{2+}$ sensitivity [12].

\subsection{Lipid Phosphorylation}

Phosphorylation of lipids can generate bioactive secondary metabolites that are capable of modulating diverse cellular processes. Phosphorylation of diacylglycerol by diacylglycerol (DAG) kinase generates phosphatidic acid (PA), an anionic lipid that has been associated with docking and priming roles, likely as a site for selective binding of different protein components [27]. In contrast, diacylglycerol has been extensively investigated in relation to its activation of PKC [113] and potential role in facilitating the initial step of membrane merger by virtue of its pronounced intrinsic negative curvature $[7,10]$. Indeed, studies of sea urchin embryos have shown that diacylglycerol modulates the fusion of precursor vesicles required for the formation of the nuclear envelope during mitosis [114]. Here, treatment of CV with the DAG kinase inhibitor R59022 selectively inhibited fusion in response to low $\left[\mathrm{Ca}^{2+}\right]_{\text {free, }}$, but only in the endpoint assay (Figure 1(Avi)); thus, as with PKC and other kinases described above, DAG kinase activity likely has a selective, but limited influence on a $\mathrm{Ca}^{2+}$ sensor.

Several recent studies have found that changes in sphingolipid levels may influence distinct stages of the regulated exocytotic pathway, either via activation of downstream signalling mechanisms that activate enzymes such as phospholipase $C$ or by accelerating the assembly of SNARE complexes [115-121]. Inhibition of sphingosine and ceramide phosphorylation leads to increased levels of these substrates and decreased levels of sphingosine-1-phosphate and ceramide-1-phosphate, respectively. Although sphingolipid biophysical properties have been shown to influence the overall curvature and permeability of model cell membranes [122], their influence on membrane merger has not been directly examined in native regulated exocytotic systems. Here, treatment of CV with NVP231, a ceramide kinase inhibitor, caused a slight potentiation in the settle fusion assay (Figure 1(Bvi)), whereas treatment with DMS, a sphingosine kinase inhibitor, potently inhibited CV fusion even in response to a saturating $\left[\mathrm{Ca}^{2+}\right]_{\text {free }}$ (Figure $1($ Avi,Bvi)). Indeed, the latter was the most significant effect of any of the compounds tested. As such, regulation of sphingolipid levels by ceramide and sphingosine kinase is implicated in modulating docking/priming and membrane fusion, respectively. 
Thus, while ceramide kinase may be a component of the PFM, sphingosine kinase is implicated as a likely component of the FFM, producing a localized supply of sphingosine-1-phosphate.

\section{Conclusions}

The study of CV fusion has enabled targeted identification of components of the conserved molecular mechanism underlying the late $\mathrm{Ca}^{2+}$-triggered steps of regulated exocytosis, and here, new high-throughput assay formats have identified candidate kinases and phosphatases, on the secretory vesicle membrane, that modulate priming/docking, $\mathrm{Ca}^{2+}$ sensitivity and membrane fusion. The new assays formats used in this study are cost-effective, provide direct access to the exocytotic mechanism(s) and do not involve cell isolation from vertebrate, mammalian sources. The results indicate the presence of multiple phosphorylation sites on proteins and lipids, localised on the secretory vesicle membrane, serving as components of both the PFM and FFM, and this is consistent with a recent analysis of protein phosphosites in synaptosomes [123]. Uniquely, the approach here also identified the critical importance of lipid phosphorylation, in particular of sphingosine. Specifically, phosphatases and CK2 are implicated in modulating $\mathrm{Ca}^{2+}$ sensitivity, and sphingosine kinase activity is implicated more directly in enabling membrane fusion. While it is also possible that kinases and phosphatases in the local cytosol might also modulate components of the PFM and FFM, here we sought only to assess the effects of vesicle-associated enzymes. In any case, it would be difficult to assess local cytosol effects or components specifically near the site of docking and fusion. This study thus defines a modified, high-throughput fusion assay format to better capitalize on the well-established CV model system. The results provide a rationale for larger scale proteomic and lipidomic analyses of $\mathrm{CV}$ membranes to identify the CK2 and phosphatase substrates and the potentially wider lipid alterations resulting from sphingosine kinase inhibition, in order to further identify critical components and correlate molecular changes with alterations in specific steps underling triggered exocytotic release. The data also provide a rationale for examining the role of CK2 and sphingosine kinase in the modulation of regulated exocytosis in mammalian cells, using techniques including high temporal resolution patch clamp assays of membrane capacitance and fusion pore expansion and a range of imaging techniques (e.g., total internal reflection fluorescence (TIRF) and stimulated emission depletion (STED) microscopy).

Acknowledgments: The authors thank N. Noaman for several helpful discussions and E.P. Wright for some initial observations; the authors also thank A. Deschamps and the Western Sydney University (WSU) School of Medicine Animal House and the Underwater Research Group of NSW for the collection and maintenance of sea urchins. P.S.A. was supported by a PhD Scholarship from the WSU School of Medicine. J.R.C. is grateful to an anonymous family foundation for providing initial financial support for this work and acknowledges funding from the National Health and Medical Research Council (NHMRC - APP1065328).

Author Contributions: P.S.A. and J.R.C. conceived of and designed the experiments. P.S.A. performed the experiments and analysed the data. P.S.A. and J.R.C. wrote the paper.

Conflicts of Interest: The authors declare no conflict of interest.

\section{References}

1. Churchward, M.A.; Coorssen, J.R. Cholesterol, regulated exocytosis and the physiological fusion machine. Biochem. J. 2009, 423, 1-14. [CrossRef] [PubMed]

2. Abbineni, P.S.; Hibbert, J.E.; Coorssen, J.R. Critical role of cortical vesicles in dissecting regulated exocytosis: Overview of insights into fundamental molecular mechanisms. Biol. Bull. 2013, 224, 200-217. [CrossRef] [PubMed]

3. Furber, K.L.; Churchward, M.A.; Rogasevskaia, T.P.; Coorssen, J.R. Identifying critical components of native $\mathrm{Ca}^{2+}$-triggered membrane fusion. Integrating studies of proteins and lipids. Ann. N. Y. Acad. Sci. 2009, 1152, 121-134. [CrossRef] [PubMed]

4. Becherer, U.; Rettig, J. Vesicle pools, docking, priming, and release. Cell Tissue Res. 2006, 326, 393-407. [CrossRef] [PubMed] 
5. Abbineni, P.S.; Wright, E.P.; Rogasevskaia, T.P.; Killingsworth, M.C.; Malladi, C.S.; Coorssen, J.R. The sea urchin egg and cortical vesicles as model systems to dissect the fast, $\mathrm{Ca}^{2+}$-triggered steps of regulated exocytosis. In Exocytosis Methods; Thorn, P., Ed.; Humana Press: New York, NY, USA, 2013; pp. 221-241.

6. Rizo, J.; Südhof, T.C. The membrane fusion enigma: SNAREs, Sec1/Munc18 proteins, and their accomplices-Guilty as charged? Ann. Rev. Cell. Dev. Biol. 2012, 28, 279-308. [CrossRef] [PubMed]

7. Churchward, M.A.; Rogasevskaia, T.; Hofgen, J.; Bau, J.; Coorssen, J.R. Cholesterol facilitates the native mechanism of $\mathrm{Ca}^{2+}$-triggered membrane fusion. J. Cell Sci. 2005, 118, 4833-4848. [CrossRef] [PubMed]

8. Rogasevskaia, T.P.; Coorssen, J.R. A new approach to the molecular analysis of docking, priming, and regulated membrane fusion. J. Chem. Biol. 2011, 4, 117-136. [CrossRef] [PubMed]

9. Rogasevskaia, T.P.; Churchward, M.A.; Coorssen, J.R. Anionic lipids in $\mathrm{Ca}^{(2+)}$-triggered fusion. Cell Calcium 2012, 52, 259-269. [CrossRef] [PubMed]

10. Churchward, M.A.; Rogasevskaia, T.; Brandman, D.M.; Khosravani, H.; Nava, P.; Atkinson, J.K.; Coorssen, J.R. Specific lipids supply critical negative spontaneous curvature-An essential component of native $\mathrm{Ca}^{2+}$-triggered membrane fusion. Biophys. J. 2008, 94, 3976-3986. [CrossRef] [PubMed]

11. Rogasevskaia, T.; Coorssen, J.R. Sphingomyelin-enriched microdomains define the efficiency of native $\mathrm{Ca}^{(2+)}$-triggered membrane fusion. J. Cell. Sci. 2006, 119, 2688-2694. [CrossRef] [PubMed]

12. Ammala, C.; Eliasson, L.; Bokvist, K.; Berggren, P.O.; Honkanen, R.E.; Sjoholm, A.; Rorsman, P. Activation of protein kinases and inhibition of protein phosphatases play a central role in the regulation of exocytosis in mouse pancreatic $\beta$ cells. Proc. Natl. Acad. Sci. USA 1994, 91, 4343-4347. [CrossRef] [PubMed]

13. Terbush, D.R.; Holz, R.W. Activation of protein kinase $C$ is not required for exocytosis from bovine adrenal chromaffin cells. The effects of protein kinase C(19-31), Ca/CaM kinase II(291-317), and staurosporine. J. Biol. Chem. 1990, 265, 21179-21184. [PubMed]

14. Scepek, S.; Coorssen, J.R.; Lindau, M. Fusion pore expansion in horse eosinophils is modulated by $\mathrm{Ca}^{2+}$ and protein kinase $C$ via distinct mechanisms. EMBO J. 1998, 17, 4340-4345. [CrossRef] [PubMed]

15. Shu, Y.; Liu, X.; Yang, Y.; Takahashi, M.; Gillis, K.D. Phosphorylation of SNAP-25 at Ser187 mediates enhancement of exocytosis by a phorbol ester in INS-1 cells. J. Neurosci. 2008, 28, 21-30. [CrossRef] [PubMed]

16. Kazanietz, M.G. Eyes wide shut: Protein kinase $C$ isozymes are not the only receptors for the phorbol ester tumor promoters. Mol. Carcinog. 2000, 28, 5-11. [CrossRef]

17. Rhee, J.S.; Betz, A.; Pyott, S.; Reim, K.; Varoqueaux, F.; Augustin, I.; Hesse, D.; Sudhof, T.C.; Takahashi, M.; Rosenmund, C.; et al. $\beta$ phorbol ester- and diacylglycerol-induced augmentation of transmitter release is mediated by Munc13s and not by PKCs. Cell 2002, 108, 121-133. [CrossRef]

18. Oh, E.; Thurmond, D.C. The stimulus-induced tyrosine phosphorylation of Munc18c facilitates vesicle exocytosis. J. Biol. Chem. 2006, 281, 17624-17634. [CrossRef] [PubMed]

19. Ohnishi, H.; Yamamori, S.; Ono, K.; Aoyagi, K.; Kondo, S.; Takahashi, M. A src family tyrosine kinase inhibits neurotransmitter release from neuronal cells. Proc. Natl. Acad. Sci. USA 2001, 98, 10930-10935. [CrossRef] [PubMed]

20. Renstrom, E.; Ding, W.G.; Bokvist, K.; Rorsman, P. Neurotransmitter-induced inhibition of exocytosis in insulin-secreting $\beta$ cells by activation of calcineurin. Neuron 1996, 17, 513-522. [CrossRef]

21. Sihra, T.S.; Nairn, A.C.; Kloppenburg, P.; Lin, Z.; Pouzat, C. A role for calcineurin (protein phosphatase-2B) in the regulation of glutamate release. Biochem. Biophys. Res. Commun. 1995, 212, 609-616. [CrossRef] [PubMed]

22. Raufman, J.P.; Malhotra, R.; Raffaniello, R.D. Regulation of calcium-induced exocytosis from gastric chief cells by protein phosphatase-2B (calcineurin). Biochim. Biophys. Acta 1997, 1357, 73-80. [CrossRef]

23. Kumashiro, S.; Lu, Y.F.; Tomizawa, K.; Matsushita, M.; Wei, F.Y.; Matsui, H. Regulation of synaptic vesicle recycling by calcineurin in different vesicle pools. Neurosci. Res. 2005, 51, 435-443. [CrossRef] [PubMed]

24. Coorssen, J.R.; Blank, P.S.; Tahara, M.; Zimmerberg, J. Biochemical and functional studies of cortical vesicle fusion: The snare complex and $\mathrm{Ca}^{2+}$ sensitivity. J. Cell Biol. 1998, 143, 1845-1857. [CrossRef] [PubMed]

25. Tahara, M.; Coorssen, J.R.; Timmers, K.; Blank, P.S.; Whalley, T.; Scheller, R.; Zimmerberg, J. Calcium can disrupt the SNARE protein complex on sea urchin egg secretory vesicles without irreversibly blocking fusion. J. Biol. Chem. 1998, 273, 33667-33673. [CrossRef] [PubMed]

26. Coorssen, J.R.; Blank, P.S.; Albertorio, F.; Bezrukov, L.; Kolosova, I.; Chen, X.; Backlund, P.S., Jr.; Zimmerberg, J. Regulated secretion: SNARE density, vesicle fusion and calcium dependence. J. Cell. Sci. 2003, 116, 2087-2097. [CrossRef] [PubMed] 
27. Rogasevskaia, T.P.; Coorssen, J.R. The role of phospholipase D in regulated exocytosis. J. Biol. Chem. 2015, 290, 28683-28696. [CrossRef] [PubMed]

28. Whalley, T.; Crossley, I.; Whitaker, M. Phosphoprotein inhibition of calcium-stimulated exocytosis in sea urchin eggs. J. Cell Biol. 1991, 113, 769-778. [CrossRef] [PubMed]

29. Sea Urchin Genome Sequencing Consortium; Sodergren, E.; Weinstock, G.M.; Davidson, E.H.; Cameron, R.A.; Gibbs, R.A.; Angerer, R.C.; Angerer, L.M.; Arnone, M.I.; Burgess, D.R.; et al. The genome of the sea urchin Strongylocentrotus purpuratus. Science 2006, 314, 941-952. [CrossRef] [PubMed]

30. Bradham, C.A.; Foltz, K.R.; Beane, W.S.; Arnone, M.I.; Rizzo, F.; Coffman, J.A.; Mushegian, A.; Goel, M.; Morales, J.; Geneviere, A.M.; et al. The sea urchin kinome: A first look. Dev. Biol. 2006, 300, 180-193. [CrossRef] [PubMed]

31. Vogel, S.S.; Zimmerberg, J. Proteins on exocytic vesicles mediate calcium-triggered fusion. Proc. Natl. Acad. Sci. USA 1992, 89, 4749-4753. [CrossRef] [PubMed]

32. Zimmerberg, J.; Blank, P.S.; Kolosova, I.; Cho, M.S.; Tahara, M.; Coorssen, J.R. A stage-specific preparation to study the $\mathrm{Ca}^{2+}$-triggered fusion steps of exocytosis: Rationale and perspectives. Biochimie 2000, 82, 303-314. [CrossRef]

33. Vogel, S.S.; Beushausen, S.; Lester, D.S. Application of a membrane fusion assay for rapid drug screening. Pharm. Res. 1995, 12, 1417-1422. [CrossRef] [PubMed]

34. Furber, K.L.; Brandman, D.M.; Coorssen, J.R. Enhancement of the $\mathrm{Ca}^{2+}$-triggering steps of native membrane fusion via thiol-reactivity. J. Chem. Biol. 2009, 2, 27-37. [CrossRef] [PubMed]

35. Abbineni, P.S.; Western Sydney University, Campbelltown, NSW, Australia; Coorssen, J.R.; Brock University, St. Catharines, ON, Canada. Unpublished work. 2017.

36. Blank, P.S.; Cho, M.S.; Vogel, S.S.; Kaplan, D.; Kang, A.; Malley, J.; Zimmerberg, J. Submaximal responses in calcium-triggered exocytosis are explained by differences in the calcium sensitivity of individual secretory vesicles. J. Gen. Physiol. 1998, 112, 559-567. [CrossRef] [PubMed]

37. Pocotte, S.L.; Frye, R.A.; Senter, R.A.; TerBush, D.R.; Lee, S.A.; Holz, R.W. Effects of phorbol ester on catecholamine secretion and protein phosphorylation in adrenal medullary cell cultures. Proc. Natl. Acad. Sci. USA 1985, 82, 930-934. [CrossRef] [PubMed]

38. Gillis, K.D.; Mossner, R.; Neher, E. Protein kinase c enhances exocytosis from chromaffin cells by increasing the size of the readily releasable pool of secretory granules. Neuron 1996, 16, 1209-1220. [CrossRef]

39. Coorssen, J.R.; Haslam, R.J. GTP gamma $S$ and phorbol ester act synergistically to stimulate both $\mathrm{Ca}^{2+}$-independent secretion and phospholipase $\mathrm{d}$ activity in permeabilized human platelets. Inhibition by BAPTA and analogues. FEBS Lett. 1993, 316, 170-174. [CrossRef]

40. Shen, S.S.; Burgart, L.J. 1,2-diacylglycerols mimic phorbol 12-myristate 13-acetate activation of the sea urchin egg. J. Cell. Physiol. 1986, 127, 330-340. [CrossRef] [PubMed]

41. Wert, M.M.; Palfrey, H.C. Divergence in the anti-apoptotic signalling pathways used by nerve growth factor and basic fibroblast growth factor (bFGF) in PC12 cells: Rescue by bFGF involves protein kinase C delta. Biochem. J. 2000, 352, 175-182. [CrossRef] [PubMed]

42. Fujioka, S.; Masuda, K.; Toguchi, M.; Ohoka, Y.; Sakai, T.; Furuyama, T.; Inagaki, S. Neurotrophic effect of semaphorin 4D in PC12 cells. Biochem. Biophys. Res. Commun. 2003, 301, 304-310. [CrossRef]

43. Young, L.H.; Balin, B.J.; Weis, M.T. Go 6983: A fast acting protein kinase C inhibitor that attenuates myocardial ischemia/reperfusion injury. Cardiovasc. Drug Rev. 2005, 23, 255-272. [CrossRef] [PubMed]

44. Carpenter, A.C.; Alexander, J.S. Endothelial PKC $\delta$ activation attenuates neutrophil transendothelial migration. Inflammat. Res. 2008, 57, 216-229. [CrossRef] [PubMed]

45. Piyanuch, R.; Sukhthankar, M.; Wandee, G.; Baek, S.J. Berberine, a natural isoquinoline alkaloid, induces NAG-1 and ATF3 expression in human colorectal cancer cells. Cancer Lett. 2007, 258, 230-240. [CrossRef] [PubMed]

46. Kobayashi, Y.; Bridle, K.R.; Ramm, G.A.; O'Neill, R.; Britton, R.S.; Bacon, B.R. Effect of phorbol ester and platelet-derived growth factor on protein kinase C in rat hepatic stellate cells. Liver Int. 2007, 27, 1066-1075. [CrossRef] [PubMed]

47. Slish, D.F.; Welsh, D.G.; Brayden, J.E. Diacylglycerol and protein kinase C activate cation channels involved in myogenic tone. Am. J. Physiol. Heart Circ. Physiol. 2002, 283, H2196-H2201. [CrossRef] [PubMed] 
48. Nagy, G.; Matti, U.; Nehring, R.B.; Binz, T.; Rettig, J.; Neher, E.; Sorensen, J.B. Protein kinase C-dependent phosphorylation of synaptosome-associated protein of $25 \mathrm{kDa}$ at Ser187 potentiates vesicle recruitment. J. NeuroSci. 2002, 22, 9278-9286. [PubMed]

49. Koh, J.Y.; Wie, M.B.; Gwag, B.J.; Sensi, S.L.; Canzoniero, L.M.; Demaro, J.; Csernansky, C.; Choi, D.W. Staurosporine-induced neuronal apoptosis. Exp. Neurol. 1995, 135, 153-159. [CrossRef] [PubMed]

50. Ling, D.S.F.; Benardo, L.S.; Serrano, P.A.; Blace, N.; Kelly, M.T.; Crary, J.F.; Sacktor, T.C. Protein kinase M zeta is necessary and sufficient for LTP maintenance. Nat. Neurosci. 2002, 5, 295-296. [CrossRef] [PubMed]

51. Toullec, D.; Pianetti, P.; Coste, H.; Bellevergue, P.; Grandperret, T.; Ajakane, M.; Baudet, V.; Boissin, P.; Boursier, E.; Loriolle, F.; et al. The bisindolylmaleimide GF 109203x is a potent and selective inhibitor of protein kinase C. J. Biol. Chem. 1991, 266, 15771-15781. [PubMed]

52. Barber, L.A.; Vasko, M.R. Activation of protein kinase $C$ augments peptide release from rat sensory neurons. J. Neurochem. 1996, 67, 72-80. [CrossRef] [PubMed]

53. Wolf, M.; Baggiolini, M. The protein-kinase inhibitor staurosporine, like phorbol esters, induces the association of protein kinase C with membranes. Biochem. Biophys. Res. Commun. 1988, 154, 1273-1279. [CrossRef]

54. Ohmichi, M.; Decker, S.J.; Pang, L.; Saltiel, A.R. Inhibition of the cellular actions of nerve growth factor by staurosporine and $\mathrm{K} 252 \mathrm{~A}$ results from the attenuation of the activity of the trk tyrosine kinase. Biochemistry 1992, 31, 4034-4039. [CrossRef] [PubMed]

55. Dewald, B.; Thelen, M.; Wymann, M.P.; Baggiolini, M. Staurosporine inhibits the respiratory burst and induces exocytosis in human neutrophils. BioChem. J. 1989, 264, 879-884. [CrossRef] [PubMed]

56. Sako, T.; Tauber, A.I.; Jeng, A.Y.; Yuspa, S.H.; Blumberg, P.M. Contrasting actions of staurosporine, a protein kinase C inhibitor, on human neutrophils and primary mouse epidermal cells. Cancer Res. 1988, 48, 4646-4650. [PubMed]

57. Watson, S.P.; McNally, J.; Shipman, L.J.; Godfrey, P.P. The action of the protein kinase C inhibitor, staurosporine, on human platelets. Evidence against a regulatory role for protein kinase $\mathrm{C}$ in the formation of inositol trisphosphate by thrombin. BioChem. J. 1988, 249, 345-350. [CrossRef] [PubMed]

58. Covian-Nares, J.F.; Smith, R.M.; Vogel, S.S. Two independent forms of endocytosis maintain embryonic cell surface homeostasis during early development. Dev. Biol. 2008, 316, 135-148. [CrossRef] [PubMed]

59. Kuo, A.L.; Cappelluti, S.; Cervantes-Cervantes, M.; Rodriguez, M.; Bush, D.S. Okadaic acid, a protein phosphatase inhibitor, blocks calcium changes, gene expression, and cell death induced by gibberellin in wheat aleurone cells. Plant Cell 1996, 8, 259-269. [CrossRef] [PubMed]

60. Dobrowsky, R.T.; Hannun, Y.A. Ceramide stimulates a cytosolic protein phosphatase. J. Biol. Chem. 1992, 267, 5048-5051. [PubMed]

61. Yatsunami, J.; Komori, A.; Ohta, T.; Suganuma, M.; Fujiki, H. Hyperphosphorylation of retinoblastoma protein and p53 by okadaic acid, a tumor promoter. Cancer Res. 1993, 53, 239-241. [PubMed]

62. Felix, M.A.; Cohen, P.; Karsenti, E. Cdc2 H1 kinase is negatively regulated by a type 2A phosphatase in the Xenopus early embryonic cell cycle: evidence from the effects of okadaic acid. EMBO J. 1990, 9, 675-683. [PubMed]

63. Gromada, J.; Hoy, M.; Buschard, K.; Salehi, A.; Rorsman, P. Somatostatin inhibits exocytosis in rat pancreatic alpha-cells by $\mathrm{G}_{\mathrm{i} 2}$-dependent activation of calcineurin and depriming of secretory granules. J. Physiol. 2001, 535, 519-532. [CrossRef] [PubMed]

64. Nagy, G.; Reim, K.; Matti, U.; Brose, N.; Binz, T.; Rettig, J.; Neher, E.; Sorensen, J.B. Regulation of releasable vesicle pool sizes by protein kinase A-dependent phosphorylation of SNAP-25. Neuron 2004, 41, 417-429. [CrossRef]

65. Baba, T.; Sakisaka, T.; Mochida, S.; Takai, Y. PKA-catalyzed phosphorylation of tomosyn and its implication in $\mathrm{Ca}^{2+}$-dependent exocytosis of neurotransmitter. J. Cell Biol. 2005, 170, 1113-1125. [CrossRef] [PubMed]

66. Hoshino, K.; Nomura, K.; Suzuki, N. Cyclic-amp-dependent activation of an inter-phylum hybrid histone-kinase complex reconstituted from sea urchin sperm-regulatory subunits and bovine heart catalytic subunits. Eur. J. Biochem. FEBS 1997, 243, 612-623. [CrossRef]

67. Sarno, S.; Reddy, H.; Meggio, F.; Ruzzene, M.; Davies, S.P.; Donella-Deana, A.; Shugar, D.; Pinna, L.A. Selectivity of 4,5,6,7-tetrabromobenzotriazole, an ATP site-directed inhibitor of protein kinase CK2 ('casein kinase-2'). FEBS Lett. 2001, 496, 44-48. [CrossRef] 
68. Sanz-Clemente, A.; Matta, J.A.; Isaac, J.T.; Roche, K.W. Casein kinase 2 regulates the NR2 subunit composition of synaptic NMDA receptors. Neuron 2010, 67, 984-996. [CrossRef] [PubMed]

69. Kitazawa, T.; Kitazawa, K. Size-dependent heterogeneity of contractile $\mathrm{Ca}^{2+}$ sensitization in rat arterial smooth muscle. J. Physiol. 2012, 590, 5401-5423. [CrossRef] [PubMed]

70. Tersteeg, C.; Heijnen, H.F.; Eckly, A.; Pasterkamp, G.; Urbanus, R.T.; Maas, C.; Hoefer, I.E.; Nieuwland, R.; Farndale, R.W.; Gachet, C.; et al. Flow-induced protrusions (FLIPRs): A platelet-derived platform for the retrieval of microparticles by monocytes and neutrophils. Circ. Res. 2014, 114, 780-791. [CrossRef] [PubMed]

71. Pedraza, C.E.; Taylor, C.; Pereira, A.; Seng, M.; Tham, C.S.; Izrael, M.; Webb, M. Induction of oligodendrocyte differentiation and in vitro myelination by inhibition of Rho-associated kinase. ASN Neuro 2014, 6. [CrossRef] [PubMed]

72. Kitazawa, T. Contractile signaling pathways in mouse prostate smooth muscle. Prostate 2013, 73, 996-1006. [CrossRef] [PubMed]

73. Golas, J.M.; Arndt, K.; Etienne, C.; Lucas, J.; Nardin, D.; Gibbons, J.; Frost, P.; Ye, F.; Boschelli, D.H.; Boschelli, F. SKI-606, a 4-anilino-3-quinolinecarbonitrile dual inhibitor of Src and Abl kinases, is a potent antiproliferative agent against chronic myelogenous leukemia cells in culture and causes regression of K562 xenografts in nude mice. Cancer Res. 2003, 63, 375-381. [PubMed]

74. Vultur, A.; Buettner, R.; Kowolik, C.; Liang, W.; Smith, D.; Boschelli, F.; Jove, R. SKI-606 (bosutinib), a novel Src kinase inhibitor, suppresses migration and invasion of human breast cancer cells. Mol. Cancer Ther. 2008, 7, 1185-1194. [CrossRef] [PubMed]

75. Borriello, A.; Caldarelli, I.; Basile, M.A.; Bencivenga, D.; Tramontano, A.; Perrotta, S.; Della Ragione, F.; Oliva, A. The tyrosine kinase inhibitor dasatinib induces a marked adipogenic differentiation of human multipotent mesenchymal stromal cells. PLoS ONE 2011, 6, e28555. [CrossRef] [PubMed]

76. Giansanti, P.; Preisinger, C.; Huber, K.V.M.; Gridling, M.; Superti-Furga, G.; Bennett, K.L.; Heck, A.J.R. Evaluating the promiscuous nature of tyrosine kinase inhibitors assessed in A431 epidermoid carcinoma cells by both chemical- and phosphoproteomics. ACS Chem. Biol. 2014, 9, 1490-1498. [CrossRef] [PubMed]

77. Xi, S.C.; Zhang, Q.; Dyer, K.F.; Lerner, E.C.; Smithgall, T.E.; Gooding, W.E.; Kamens, J.; Grandis, J.R. Src kinases mediate STAT growth pathways in squamous cell carcinoma of the head and neck. J. Biol. Chem. 2003, 278, 31574-31583. [CrossRef] [PubMed]

78. Hossaina, M.I.; Hoquel, A.; Lessene, G.; Kamaruddin, M.A.; Chu, P.W.Y.; Ng, I.H.W.; Irtegun, S.; Ng, D.C.H.; Bogoyevitch, M.A.; Burgess, A.W.; et al. Dual role of Src kinase in governing neuronal survival. Brain Res. 2015, 1594, 1-14. [CrossRef] [PubMed]

79. Pene-Dumitrescu, T.; Peterson, L.F.; Donato, N.J.; Smithgall, T.E. An inhibitor-resistant mutant of Hck protects CML cells against the antiproliferative and apoptotic effects of the broad-spectrum Src family kinase inhibitor A-419259. Oncogene 2008, 27, 7055-7069. [CrossRef] [PubMed]

80. Meyn, M.A.; Schreiner, S.J.; Dumitrescu, T.P.; Nau, G.J.; Smithgall, T.E. Src family kinase activity is required for murine embryonic stem cell growth and differentiation. Mol. Pharmacol. 2005, 68, 1320-1330. [CrossRef] [PubMed]

81. Hsu, L.W.; Lee, P.L.; Chen, C.T.; Mi, F.L.; Juang, J.H.; Hwang, S.M.; Ho, Y.C.; Sung, H.W. Elucidating the signaling mechanism of an epithelial tight-junction opening induced by chitosan. Biomaterials 2012, 33, 6254-6263. [CrossRef] [PubMed]

82. Shakiryanova, D.; Klose, M.K.; Zhou, Y.; Gu, T.; Deitcher, D.L.; Atwood, H.L.; Hewes, R.S.; Levitan, E.S. Presynaptic ryanodine receptor-activated calmodulin kinase II increases vesicle mobility and potentiates neuropeptide release. J. NeuroSci. 2007, 27, 7799-7806. [CrossRef] [PubMed]

83. Gardner, A.J.; Knott, J.G.; Jones, K.T.; Evans, J.P. CAMKII can participate in but is not sufficient for the establishment of the membrane block to polyspermy in mouse eggs. J. Cell. Physiol. 2007, 212, 275-280. [CrossRef] [PubMed]

84. Yurimoto, S.; Fujimoto, T.; Magari, M.; Kanayama, N.; Kobayashi, R.; Tokumitsu, H. In vitro substrate phosphorylation by $\mathrm{Ca}^{2+} /$ calmodulin-dependent protein kinase kinase using guanosine- 5 -triphosphate as a phosphate donor. BMC Biochem. 2012, 13, 27. [CrossRef] [PubMed]

85. Hurley, R.L.; Anderson, K.A.; Franzone, J.M.; Kemp, B.E.; Means, A.R.; Witters, L.A. The Ca ${ }^{2+} /$ calmodulin- $^{-}$ dependent protein kinase kinases are AMP-activated protein kinase kinases. J. Biol. Chem. 2005, 280, 29060-29066. [CrossRef] [PubMed] 
86. Tokumitsu, H.; Inuzuka, H.; Ishikawa, Y.; Kobayashi, R. A single amino acid difference between $\alpha$ and $\beta$ $\mathrm{Ca}^{2+} /$ calmodulin-dependent protein kinase kinase dictates sensitivity to the specific inhibitor, STO-609. J. Biol. Chem. 2003, 278, 10908-10913. [CrossRef] [PubMed]

87. Tokumitsu, H.; Inuzuka, H.; Ishikawa, Y.; Ikeda, M.; Saji, I.; Kobayashi, R. STO-609, a specific inhibitor of the $\mathrm{Ca}^{2+}$ /calmodulin-dependent protein kinase kinase. J. Biol. Chem. 2002, 277, 15813-15818. [CrossRef] [PubMed]

88. Holden, N.J.; Savage, C.O.S.; Young, S.P.; Wakelam, M.J.; Harper, L.; Williams, J.M. A dual role for diacylglycerol kinase generated phosphatidic acid in autoantibody-induced neutrophil exocytosis. Mol. Med. 2011, 17, 1242-1252. [CrossRef] [PubMed]

89. Ohtsuka, T.; Hiura, M.; Yoshida, K.; Okamura, N.; Ishibashi, S. A diacylglycerol kinase inhibitor, R 59 022, potentiates superoxide anion production and 46-kDa protein phosphorylation in guinea pig polymorphonuclear leukocytes. J. Biol. Chem. 1990, 265, 15418-15423. [PubMed]

90. Niwa, S.; Graf, C.; Bornancin, F. Ceramide kinase deficiency impairs microendothelial cell angiogenesis in vitro. Microvasc. Res. 2009, 77, 389-393. [CrossRef] [PubMed]

91. Bornancin, F. Ceramide kinase: The first decade. Cell. Signal. 2011, 23, 999-1008. [CrossRef] [PubMed]

92. Graf, C.; Rovina, P.; Bornancin, F. A secondary assay for ceramide kinase inhibitors based on cell growth inhibition by short-chain ceramides. Anal. Biochem. 2009, 384, 166-169. [CrossRef] [PubMed]

93. Graf, C.; Klumpp, M.; Habig, M.; Rovina, P.; Billich, A.; Baumruker, T.; Oberhauser, B.; Bornancin, F. Targeting ceramide metabolism with a potent and specific ceramide kinase inhibitor. Mol. Pharmacol. 2008, 74, 925-932. [CrossRef] [PubMed]

94. McDonald, R.A.; Pyne, S.; Pyne, N.J.; Grant, A.; Wainwright, C.L.; Wadsworth, R.M. The sphingosine kinase inhibitor $N, N$-dimethylsphingosine inhibits neointimal hyperplasia. Br. J. Pharmacol. 2010, 159, 543-553. [CrossRef] [PubMed]

95. Ruegg, U.T.; Burgess, G.M. Staurosporine, K-252 and UCN-0: potent but nonspecific inhibitors of protein kinases. Trends Pharmacol. Sci. 1989, 10, 218-220. [CrossRef]

96. Meggio, F.; Deana, A.D.; Ruzzene, M.; Brunati, A.M.; Cesaro, L.; Guerra, B.; Meyer, T.; Mett, H.; Fabbro, D.; Furet, P.; et al. Different susceptibility of protein kinases to staurosporine inhibition. Kinetic-studies and molecular-bases for the resistance of protein-kinase CK2. Eur. J. Biochem. 1995, 234, 317-322. [CrossRef] [PubMed]

97. Adachi, J.; Kishida, M.; Watanabe, S.; Hashimoto, Y.; Fukamizu, K.; Tomonaga, T. Proteome-wide discovery of unknown ATP-binding proteins and kinase inhibitor target proteins using an ATP probe. J. Proteom. Res. 2014, 13, 5461-5470. [CrossRef] [PubMed]

98. Messa, M.; Congia, S.; Defranchi, E.; Valtorta, F.; Fassio, A.; Onofri, F.; Benfenati, F. Tyrosine phosphorylation of synapsin I by Src regulates synaptic-vesicle trafficking. J. Cell Sci. 2010, 123, 2256-2265. [CrossRef] [PubMed]

99. Gromada, J.; Hoy, M.; Renstrom, E.; Bokvist, K.; Eliasson, L.; Gopel, S.; Rorsman, P. CaM kinase II-dependent mobilization of secretory granules underlies acetylcholine-induced stimulation of exocytosis in mouse pancreatic B-cells. J. Physiol. 1999, 518, 745-759. [CrossRef] [PubMed]

100. Wu, X.S.; Wu, L.G. Protein kinase $\mathrm{C}$ increases the apparent affinity of the release machinery to $\mathrm{Ca}^{2+}$ by enhancing the release machinery downstream of the $\mathrm{Ca}^{2+}$ sensor. J. Neurosci. 2001, 21, 7928-7936. [PubMed]

101. Yawo, H. Protein kinase $C$ potentiates transmitter release from the chick ciliary presynaptic terminal by increasing the exocytotic fusion probability. J. Physiol. 1999, 515, 169-180. [CrossRef] [PubMed]

102. Yang, Y.; Gillis, K.D. A highly $\mathrm{Ca}^{2+}$-sensitive pool of granules is regulated by glucose and protein kinases in insulin-secreting INS-1 cells. J. Gen. Physiol. 2004, 124, 641-651. [CrossRef] [PubMed]

103. Coorssen, J.R.; Davidson, M.M.; Haslam, R.J. Factors affecting dense and $\alpha$-granule secretion from electropermeabilized human platelets: $\mathrm{Ca}^{2+}$-independent actions of phorbol ester and GTP $\gamma$ S. Cell Regul. 1990, 1, 1027-1041. [CrossRef] [PubMed]

104. Berg, L.K.; Wessel, G.M. Cortical granules of the sea urchin translocate early in oocyte maturation. Development 1997, 124, 1845-1850. [PubMed]

105. Sakisaka, T.; Baba, T.; Tanaka, S.; Izumi, G.; Yasumi, M.; Takai, Y. Regulation of SNAREs by tomosyn and ROCK: Implication in extension and retraction of neurites. J. Cell Biol. 2004, 166, 17-25. [CrossRef] [PubMed] 
106. Hammar, E.; Tomas, A.; Bosco, D.; Halban, P.A. Role of the Rho-ROCK (Rho-associated kinase) signaling pathway in the regulation of pancreatic $\beta$-cell function. Endocrinology 2009, 150, 2072-2079. [CrossRef] [PubMed]

107. Frantz, C.; Coppola, T.; Regazzi, R. Involvement of Rho GTPases and their effectors in the secretory process of PC12 cells. Exp. Cell Res. 2002, 273, 119-126. [CrossRef] [PubMed]

108. Rickman, C.; Duncan, R.R. Munc18/syntaxin interaction kinetics control secretory vesicle dynamics. J. Biol. Chem. 2010, 285, 3965-3972. [CrossRef] [PubMed]

109. Nielander, H.B.; Onofri, F.; Valtorta, F.; Schiavo, G.; Montecucco, C.; Greengard, P.; Benfenati, F. Phosphorylation of VAMP/synaptobrevin in synaptic vesicles by endogenous protein kinases. J. Neurochem. 1995, 65, 1712-1720. [CrossRef] [PubMed]

110. Shata, A.; Saisu, H.; Odani, S.; Abe, T. Phosphorylated synaphin/complexin found in the brain exhibits enhanced SNARE complex binding. Biochem. Biophys. Res. Commun. 2007, 354, 808-813. [CrossRef] [PubMed]

111. Gil, C.; Falques, A.; Sarro, E.; Cubi, R.; Blasi, J.; Aguilera, J.; Itarte, E. Protein kinase CK2 associates to lipid rafts and its pharmacological inhibition enhances neurotransmitter release. FEBS Lett. 2011, 585, 414-420. [CrossRef] [PubMed]

112. Snyder, D.A.; Kelly, M.L.; Woodbury, D.J. SNARE complex regulation by phosphorylation. Cell BioChem. Biophys 2006, 45, 111-123. [CrossRef]

113. Morgan, A.; Burgoyne, R.D.; Barclay, J.W.; Craig, T.J.; Prescott, G.R.; Ciufo, L.F.; Evans, G.J.; Graham, M.E. Regulation of exocytosis by protein kinase C. BioChem. Soc. Trans. 2005, 33, 1341-1344. [CrossRef] [PubMed]

114. Domart, M.C.; Hobday, T.M.; Peddie, C.J.; Chung, G.H.; Wang, A.; Yeh, K.; Jethwa, N.; Zhang, Q.; Wakelam, M.J.; Woscholski, R.; et al. Acute manipulation of diacylglycerol reveals roles in nuclear envelope assembly \& endoplasmic reticulum morphology. PLoS ONE 2012, 7, e51150.

115. Darios, F.; Wasser, C.; Shakirzyanova, A.; Giniatullin, A.; Goodman, K.; Munoz-Bravo, J.L.; Raingo, J.; Jorgacevski, J.; Kreft, M.; Zorec, R.; et al. Sphingosine facilitates snare complex assembly and activates synaptic vesicle exocytosis. Neuron 2009, 62, 683-694. [CrossRef] [PubMed]

116. Kajimoto, T.; Okada, T.; Yu, H.; Goparaju, S.K.; Jahangeer, S.; Nakamura, S. Involvement of sphingosine-1 -phosphate in glutamate secretion in hippocampal neurons. Mol. Cell. Biol. 2007, 27, 3429-3440. [CrossRef] [PubMed]

117. Flasker, A.; Jorgacevski, J.; Calejo, A.I.; Kreft, M.; Zorec, R. Vesicle size determines unitary exocytic properties and their sensitivity to sphingosine. Mol. Cell. Endocrinol. 2013, 376, 136-147. [CrossRef] [PubMed]

118. Matsushita, K.; Morrell, C.N.; Lowenstein, C.J. Sphingosine 1-phosphate activates weibel-palade body exocytosis. Proc. Natl. Acad. Sci. USA 2004, 101, 11483-11487. [CrossRef] [PubMed]

119. Suhaiman, L.; De Blas, G.A.; Obeid, L.M.; Darszon, A.; Mayorga, L.S.; Belmonte, S.A. Sphingosine 1-phosphate and sphingosine kinase are involved in a novel signaling pathway leading to acrosomal exocytosis. J. Biol. Chem. 2010, 285, 16302-16314. [CrossRef] [PubMed]

120. Trkov, S.; Stenovec, M.; Kreft, M.; Potokar, M.; Parpura, V.; Davletov, B.; Zorec, R. Fingolimod-A sphingosine-like molecule inhibits vesicle mobility and secretion in astrocytes. Glia 2012, 60, 1406-1416. [CrossRef] [PubMed]

121. Camoletto, P.G.; Vara, H.; Morando, L.; Connell, E.; Marletto, F.P.; Giustetto, M.; Sassoe-Pognetto, M.; Van Veldhoven, P.P.; Ledesma, M.D. Synaptic vesicle docking: Sphingosine regulates syntaxin1 interaction with Munc18. PLoS ONE 2009, 4, e5310. [CrossRef] [PubMed]

122. Goni, F.M.; Alonso, A. Biophysical properties and membrane organization of ceramides, ceramide-1-phosphate and other simple sphingolipids. Chem. Phys. Lip. 2009, 160, S2. [CrossRef]

123. Kohansal-Nodehi, M.; Chua, J.J.; Urlaub, H.; Jahn, R.; Czernik, D. Analysis of protein phosphorylation in nerve terminal reveals extensive changes in active zone proteins upon exocytosis. eLife 2016, 5, e14530. [CrossRef] [PubMed]

(c) 2017 by the authors. Licensee MDPI, Basel, Switzerland. This article is an open access article distributed under the terms and conditions of the Creative Commons Attribution (CC BY) license (http:/ / creativecommons.org/licenses/by/4.0/). 